\title{
Sedimentology and Sequence Stratigraphy of the Lower Cretaceous Fortress Mountain and Torok Formations Exposed Along the Siksikpuk River, North-Central Alaska
}

\author{
By David W. Houseknecht, Christopher J. Schenk, and Marwan A. Wartes ${ }^{1}$
}

\begin{abstract}
An exposure of the Lower Cretaceous Fortress Mountain and Torok Formations along the Siksikpuk River in north-central Alaska provides a rare opportunity to observe the stratigraphic contact between these two formations and to interpret the depositional facies and sequence stratigraphy of the exposed strata. The Fortress Mountain Formation at the base of the measured section includes braided-fluvial and coastalplain facies deposited in a lowstand-systems tract, and an overlying succession of mostly shallow marine facies deposited in the basal part of a transgressive-systems tract. The overlying Torok Formation includes a thick, upward-deepening succession of marine-shelf to marine-slope facies deposited in the upper part of the transgressive-systems tract. The upper part of the section includes marine-slope and incised-slope-channel turbidite deposits of the Torok Formation, interpreted as a highstand-systems tract.

Consideration of the balance between accommodation and sediment flux inferred from the sequence-stratigraphic analysis suggests that both tectonics and eustasy may have influenced deposition of the lowstand-systems and transgressive-systems tracts. In contrast, the highstand-systems tract may have been primarily influenced by progradation of a regional sediment-dispersal system and by subsidence induced by sediment loading.
\end{abstract}

\section{Introduction}

The Brookian tectonostratigraphic sequence of northern Alaska (fig. 1) includes Cretaceous and Tertiary strata that reflect the evolution of the Colville foreland basin (Lerand, 1973; Hubbard and others, 1987; Bird and Molenaar, 1992). The Albian through Miocene part of the Brookian sequence

${ }^{1}$ Alaska Division of Geological and Geophysical Surveys. Manuscript approved for publication, October 4, 2007. (fig. 2) is well known from numerous studies that have documented stratal geometries and depositional facies in outcrops and the subsurface (Molenaar, 1983, 1985; Huffman, 1985; Houseknecht and Schenk, 2001). In contrast, the pre-Albian part of the Brookian sequence (fig. 2) is less well known because those strata are more structurally deformed and dissected by erosion in the Brooks Range foothills and because few subsurface datasets include information on these rocks.

The Fortress Mountain Formation and related parts of the Torok Formation (strata of Barremian?, Aptian, and early Albian? age) are the focus of this chapter. Despite studies that have advanced knowledge of the depositional facies and regional stratigraphy of these rocks (for example, Hunter and Fox, 1976; Crowder, 1987, 1989; Molenaar and others, 1988; Wartes and Carroll, 2002), interpretations of the sedimentology of the Fortress Mountain Formation include wide-ranging depictions of depositional environments, and demonstrable stratigraphic relations between the Fortress Mountain Formation (mostly sandstone and conglomerate) and the Torok Formation (mostly mudstone) remain poorly understood.

An outcrop of the upper part of the Fortress Mountain Formation and the overlying Torok Formation along the Siksikpuk River (fig. 1) provides a rare opportunity to directly observe a contact between these two formations. The objectives of this chapter are to describe and interpret the succession of facies exposed there, to interpret the sequence-stratigraphic framework of those facies, and to infer the significance of these interpretations to the regional paleogeography of the Colville foreland basin.

\section{Geologic Setting}

The study area (fig. 1) is in the southern foothills of the Brooks Range, an area of mostly Lower Cretaceous forelandbasin deposits deformed by northward-vergent thrust faults and folds (Moore and others, 1994). A chronostratigraphic column of the Fortress Mountain and Torok Formations in the context of the Brookian sequence is shown in figure 2. The rocks exposed along the Siksikpuk River provide insights 


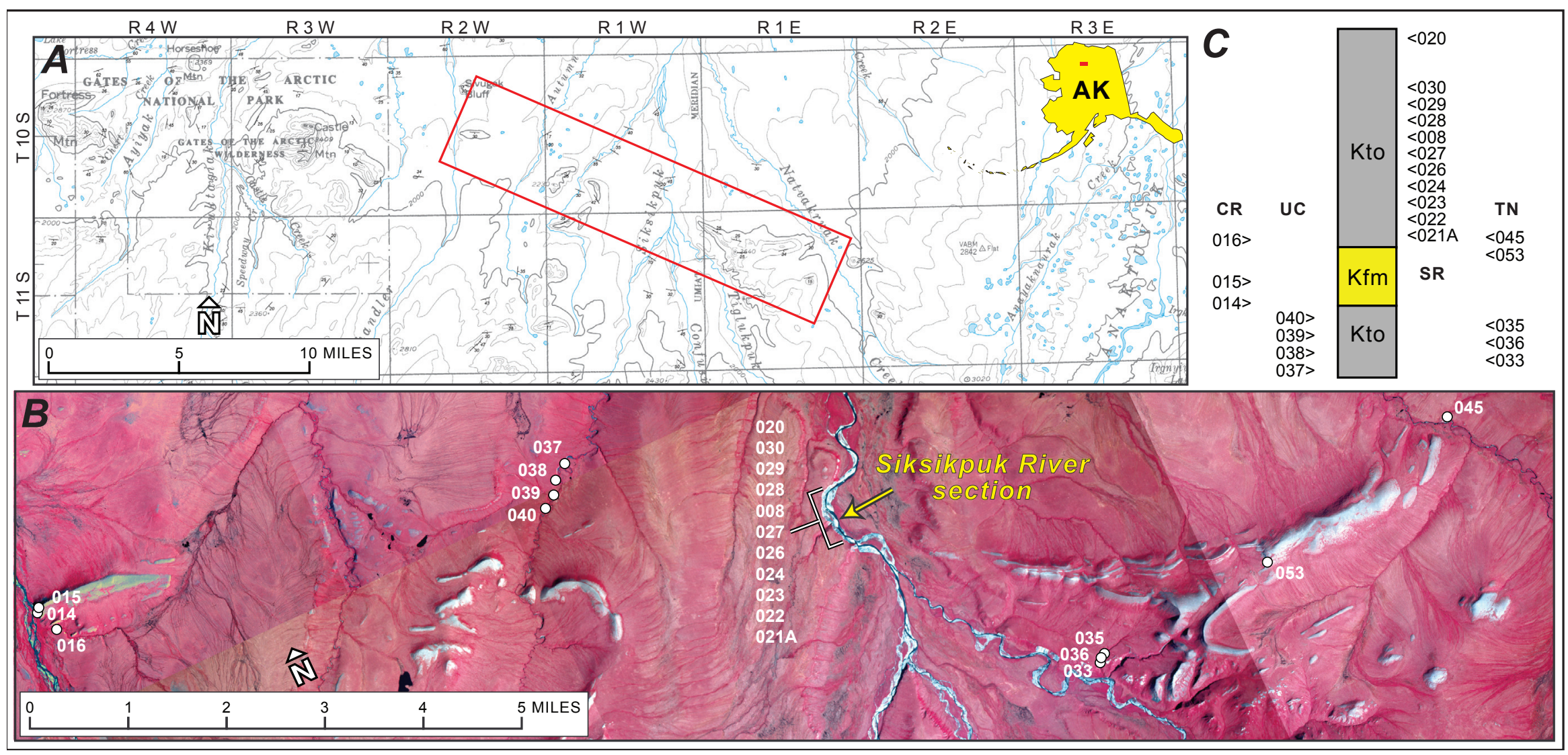

Figure 1. Siksikpuk River area, north-central Alaska, showing locations of measured section and samples for which paleontologic results are reported in this chapter. $A$, Part of the Chandler Lake 1:250,000-scale quadrangle, showing location of study area (red rectangle) east of the Fortress and Castle Mountains and west of the Anaktuvuk River. $B$, False-color infrared aerial photomosaic of study area. All resistant ridges with fold geometries are exposures of the Fortress Mountain Formation. White bracket and white dots show locations of paleontologic samples from measured section on the Siksikpuk River and other nearby exposures. All sample numbers are listed in table 1 with USGS prefix "05DH-". C, Sketch showing stratigraphic position of paleontologic samples relative to the Fortress Mountain Formation; no vertical scale. Kfm, Fortress Mountain Formation; Kto, Torok Formation. Localities: CR, Chandler River; SR, Siksikpuk River; TN, Tiglukpuk Creek-Natvakruak Creek; UC, unnamed creek. 
regarding the lateral and vertical relations between the Fortress Mountain and Torok Formations (red rectangle, fig. 2).

Most previous work on this part of the stratigraphic section has focused on the Fortress Mountain Formation, which commonly is well exposed because its thick sandstone and conglomerate beds generally are resistant to erosion. The Fortress Mountain Formation is considered Aptian through early Albian, although the older age is poorly constrained (Molenaar and others, 1988). The formation, which is as much as 9,000 $\mathrm{ft}$ thick, includes sandstone and conglomerate interpreted as turbidite through alluvial-fan deposits (Hunter and Fox, 1976; Crowder, 1987, 1989; Molenaar and others, 1988; Wartes and Carroll, 2002). Most workers agree that the Fortress Mountain Formation represents sediment shed northward from the Brooks Range into the southern part of the Colville foreland basin and that the formation thins northward, grades from fluvial to turbidite facies, and interfingers with basinal mudstone of the Torok Formation.

The Torok Formation, which is inferred to span late Barremian(?) through Cenomanian time (fig. 2), consists predominately of mudstone with interbedded sandstone. The Torok is best known from outcrops in the northern foothills of the Brooks Range and from seismic data and wells drilled beneath the northern foothills and coastal plain. In those areas, the Torok is mostly Albian to Cenomanian and is regarded as marine-slope and deep-basin facies associated with marine-shelf, delta, and nonmarine facies of the Nanushuk Formation (Mull, 1985; Molenaar, 1988; Bird and Molenaar, 1992; Houseknecht and Schenk, 2001). The Torok Formation includes turbidite sandstone facies deposited in incised slope channels and in basin-floor submarine fans; these facies are locally oil stained in outcrop and are oil productive in the Nanuq oil pool of the Alpine oil field (Houseknecht and Schenk, in press). The Torok is less well known in the southern foothills, where it has been inferred to underlie, interfinger with, and overlie the Fortress Mountain Formation (fig. 2). Observable contacts in outcrop between the Fortress Mountain and Torok Formations are rare, and subsurface data are too sparse and poor to resolve uncertainties of the relations between the two formations.

Previous workers have inferred that bottomset seismic reflections in the lower part of the Brookian sequence beneath the northern foothills of the Brooks Range represent distal stratigraphic equivalents of the Fortress Mountain Formation (Molenaar and others, 1988; Cole and others, 1997). Direct evidence of this relation, however, is absent because seismic data available for the present work do not clearly image the southern margin of the Colville foreland basin, owing to structural complexity. Moreover, Houseknecht and Schenk (2001) inferred, on the basis of seismic evidence from beneath the northern foothills, that the bottomset seismic reflections are east-dipping clinoforms within the Torok Formation deposited in the Colville foredeep during lowstands of relative sea level. Thus, the stratigraphic and facies relations between the Fortress Mountain and Torok Formations remain vague.

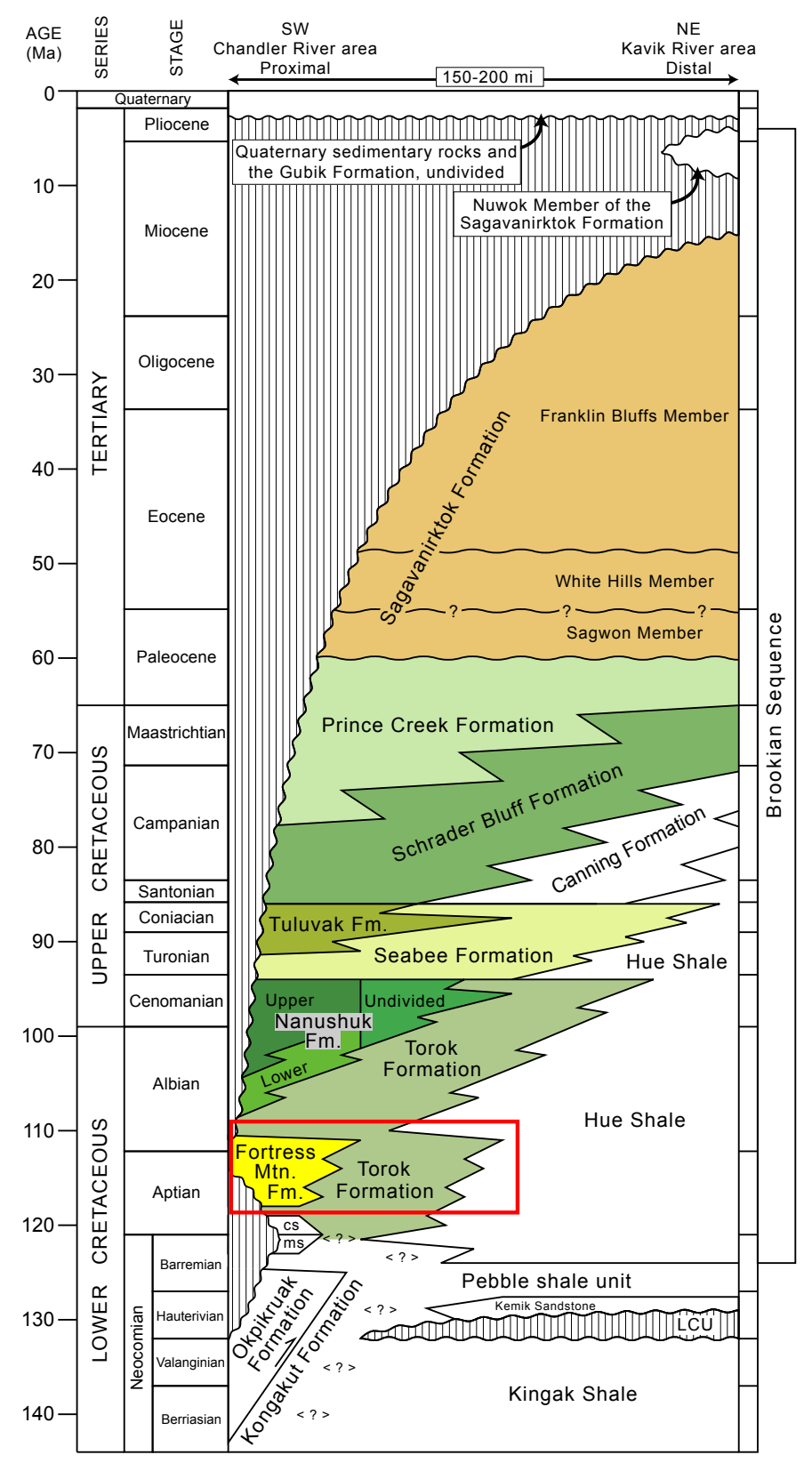

Figure 2. Chronostratigraphic column for the Colville foreland basin, northern Alaska, showing nomenclature and ages of strata of the Brookian sequence. Strata enclosed by red rectangle are reported on in this chapter. cs, Cobblestone Sandstone of the Fortress Mountain Formation; LCU, Lower Cretaceous unconformity; ms, manganiferous shale (informal term). Stratigraphic column modified from Mull and others (2003); geologic time scale from Gradstein and $0 \mathrm{gg}$ (1996) and U.S. Geological Survey Geologic Names Committee (2007). Query, relation uncertain. 


\section{Biostratigraphy}

Mudstone samples from the Fortress Mountain and Torok Formations collected from the Siksikpuk River section and nearby exposures span the stratigraphic section from $\sim 1,000$ $\mathrm{ft}$ below to $\sim 1,000 \mathrm{ft}$ above the Fortress Mountain Formation (fig. 1C). Biostratigraphic ages were estimated on the basis of independent analyses of palynomorphs and foraminifers concentrated from those samples (Mickey, 2006; Ravn, 2006). A few megafossils from the Siksikpuk River section were identified by William P. Elder, who also interpreted probable ages and general depositional environments.

The results of palynologic analysis suggest that all the samples are Aptian (fig. 1; table 1), correlative with the upper part of the Kuparuk and the lowermost part of the Kalubik Formations (nomenclature of Carman and Hardwick, 1983; Ravn, 2006) in the subsurface of the Alaskan North Slope. Results of foraminiferal analysis suggest ages as old as Hauterivian through Barremian for some of the stratigraphically lowest samples, and as young as Aptian through early Albian for some of the stratigraphically highest samples (fig. 1; table 1; Mickey, 2006). Generalized paleoenvironmental interpretations based on foraminiferal analysis are summarized in table 1. The results of megafossil analysis suggest ages of Hauterivian through Albian for the samples (see pl. 1).

We have not attempted to integrate the results of these biostratigraphic studies or to reconcile differences in estimated ages. The information is included here mainly for completeness and to help constrain the interpretation of depositional facies.

\section{Siksikpuk River Section}

The measured section in the study area (fig. 1) is a cutbank on the west side of the Siksikpuk River in sec. 35, T. 10 S., R. 1 W. (lat $68.531^{\circ}$ N., long $152.055^{\circ}$ W.). Strata in the Siksikpuk River section crop out on the south limb of a syncline (fig. 1), with strikes of $90-125^{\circ}$ and dips generally ranging from $60^{\circ}$ to $75^{\circ} \mathrm{N}$. Steeply overturned beds dipping $75-85^{\circ} \mathrm{S}$. are present locally (see pl. 1); these local structural complexities have recently been addressed by Peapples and others (2007). The upper part of the Fortress Mountain Formation and overlying Torok Formation are exposed in the Siksikpuk River section; the contact between the two formations is placed at $\sim 200 \mathrm{ft}$, at the top of an interval that grades from sandstone below to mudstone above (pl. 1). This contact also corresponds to the base of a 10-ft-thick fault zone, as discussed below. Neither the base of the Fortress Mountain Formation nor the top of the Torok Formation is exposed in the measured section.

The Siksikpuk River section (see pl. 1; fig. 1) was measured and described in July 2005. Of the $\sim 2,500 \mathrm{ft}$ of section, the lower $950 \mathrm{ft}$ is fully exposed, the middle $750 \mathrm{ft}$ is partly covered, and the upper $800 \mathrm{ft}$ is fully exposed (see pl. 1).
The section is cut by a fault zone (200-210 ft, pl. 1) that dips shallowly north. The fault appears to be a southward-vergent, out-of-syncline thrust fault; however, the sense of displacement relative to the measured section is that of a normal fault because the strata dip steeply north and the fault dips shallowly north - in other words, if the strata were rotated to the horizontal, the fault would appear to be a steeply south dipping normal fault. The net effect is that a "fault gap" of $~ 250$ $\mathrm{ft}$ of strata is omitted from the measured section. The section may also be cut by one or more additional faults or recumbent folds between 800 and 1,000 ft (pl. 1). That part of the section, characterized by dark fissile mudstone, displays locally varying dips and overturned beds, features that may indicate faulting and (or) folding, although no such discrete structures were identified in outcrop.

A gamma-ray profile of the Siksikpuk River section (see pl. 1; fig. 1) was collected with a spectrometer equipped with an internal stabilization source (Cs). Output from the spectrometer included estimates of $\mathrm{K}$, Th, and $\mathrm{U}$ contents, which were converted to total gamma-ray exposure by using the relation of Grasty and others (1984). Gamma-ray spectra were collected throughout the measured section, with the distance between collection spots determined by lithologic heterogeneity and outcrop accessibility; collection time for each gammaray spectrum was 3 minutes.

\section{Sedimentology}

The lower $200 \mathrm{ft}$ of the Siksikpuk River section (see pl. 1; fig. 1) comprises interbedded conglomerate, sandstone, siltstone, and mudstone assigned to the Fortress Mountain Formation. This part of the section is divided into four units, A through $\mathrm{D}$ in ascending order, for the purposes of describing and interpreting depositional facies.

\section{Fortress Mountain Formation}

\section{Unit A}

Description.-Unit A, $52 \mathrm{ft}$ thick, comprises mostly trough crossbedded conglomerate and conglomeratic sandstone (see pl. 1). At least $30 \mathrm{ft}$ of additional conglomerate is poorly exposed on the hillside below (south of) the base of the measured section. The conglomerate beds contain clasts that are mostly pebble to cobble size and poorly to moderately sorted. Most conglomerate beds are matrix supported, and the matrix ranges in composition from sandstone to muddy sandstone; some beds grade laterally into pebbly sandstone. Maximum clast size is most commonly $\sim 2$ in. in diameter, but some clasts are as large as 4 in. in diameter (fig. 3). Clasts are composed predominately of chert in various colors (commonly medium gray, dark gray, black, green, and red), and clasts of green sandstone and tasmanite (Tourtelot and Tailleur, 1965) were also observed (fig. 3). The chert clasts are mostly non- 
Table 1. Inferred ages of strata in the Fortress Mountain and Torok Formations exposed along the Siksikpuk River and vicinity, north-central Alaska, based on palynologic and foraminiferal biostratigraphic analyses and depositional environments inferred from foraminiferal micropaleontologic analyses.

[Samples are listed in the stratigraphic positions inferred from field observations. Palynologic analyses from Ravn (2006); foraminiferal analyses from Mickey (2006)]

\begin{tabular}{|c|c|c|c|}
\hline \multirow[t]{2}{*}{ Sample (fig. 1) } & \multirow{2}{*}{$\begin{array}{l}\text { Palynology } \\
\text { Inferred age }\end{array}$} & \multicolumn{2}{|c|}{ Foraminiferal micropaleontology } \\
\hline & & Inferred age & Depositional environment \\
\hline \multicolumn{4}{|c|}{ Chandler River } \\
\hline 05DH-016 & Aptian & Aptian through early Albian & Upper to middle bathyal \\
\hline 05DH-015 & Aptian & Probable Hauterivian through Barremian & Lower bathyal \\
\hline 05DH-014 & Aptian & Aptian through Albian, undifferentiated & Possible bathyal \\
\hline \multicolumn{4}{|c|}{ Unnamed creek } \\
\hline $05 \mathrm{DH}-037$ & Aptian & Probable Barremian & Middle to lower bathyal \\
\hline 05DH-038 & Aptian & Barremian through early Aptian & Bathyal \\
\hline 05DH-039 & Aptian & Early Cretaceous, undifferentiated & Marine \\
\hline 05DH-040 & Aptian & Aptian through Albian, undifferentiated & Middle neritic to middle bathyal \\
\hline \multicolumn{4}{|c|}{ Siksikpuk River } \\
\hline $05 \mathrm{DH}-020$ & Aptian & Aptian through Albian, undifferentiated & Bathyal \\
\hline 05DH-030 & Aptian & Barremian through early Aptian & Middle to lower bathyal \\
\hline 05DH-028 & Aptian & Barremian through early Aptian & Middle to lower bathyal \\
\hline 05DH-008 & Aptian & Barremian through early Aptian & Middle to lower bathyal \\
\hline 05DH-027 & Aptian & Barremian through early Aptian & Middle to lower bathyal \\
\hline 05DH-026 & Aptian & Barremian through early Aptian & Outer neritic to upper bathyal \\
\hline $05 \mathrm{DH}-025$ & Aptian & Aptian through early Albian & Outer neritic to middle bathyal \\
\hline 05DH-024 & Aptian & Aptian through early Albian & Middle to lower bathyal \\
\hline 05DH-023 & Aptian & Aptian through early Albian & Middle to lower bathyal \\
\hline 05DH-022 & Aptian & Aptian through early Albian & Middle to lower bathyal \\
\hline $05 \mathrm{DH}-021 \mathrm{~A}$ & Aptian & Aptian through early Albian & Outer neritic to middle bathyal \\
\hline \multicolumn{4}{|c|}{ Tiglukpuk Creek-Natvakruak Creek } \\
\hline $05 \mathrm{DH}-045$ & Aptian & Indeterminate & Indeterminate (barren of foraminifers) \\
\hline $05 \mathrm{DH}-053$ & Aptian & Indeterminate & Indeterminate (barren of foraminifers) \\
\hline 05DH-035 & Aptian & Hauterivian through Barremian & Upper to middle bathyal \\
\hline 05DH-036 & Aptian & Hauterivian through Barremian & Upper to middle bathyal \\
\hline $05 \mathrm{DH}-033$ & Aptian & Barremian through early Aptian & Upper to middle bathyal \\
\hline
\end{tabular}

spherical and subangular to subrounded. The sandstone interbeds are medium to coarse grained and pebbly and display a predominance of trough crossbedding. The maximum thickness of crossbed sets ranges from 3 to $8 \mathrm{ft}$, and most troughcrossbedded sets are 20 to $40 \mathrm{ft}$ wide. In the upper $10 \mathrm{ft}$ of the unit, trough-shaped beds composing fining-upward intervals of sandstone to mudstone are interleaved with trough-shaped beds of coarse-grained to very coarse grained sandstone. Most of the unit is characterized by low gamma-ray values and a blocky log motif (pl. 1). The upper $10 \mathrm{ft}$ is characterized by an upward increase in gamma-ray values through an 8-ft-thick bed fining upward from sandstone to mudstone and an abrupt return to low gamma-ray values in a thin ( $2 \mathrm{ft}$ thick) conglomerate bed at the top of the unit.

Interpretation.-We interpret unit A as the deposits of low-sinuosity fluvial channels, probably representing a braided-fluvial system on a coastal plain or an alluvial fan. The trough-crossbedded conglomerate and coarse-grained sandstone beds are typical of channel-fill deposits in braided streams, which commonly are characterized by relatively high gradient, high bedload, and flashy discharge. The bedding dimensions, in combination with the coarse grain size and textural immaturity (poorly sorted sediment and generally immature clast shape), suggest deposition in a relatively proximal part of the fluvial system, not far removed from the sediment source terrane, probably in a fluvial system prone to flashy discharge and hyperconcentrated flows. The interval fining upward from sandstone to mudstone at the top of the unit is interpreted as a channel-abandonment facies, suggesting either abandonment of the fluvial system or switching of the locus of fluvial deposition to another part of the coastal plain, possibly as a result of avulsion.

\section{Unit B}

Description.-Unit B, $56.5 \mathrm{ft}$ thick, consists of relatively thin beds of siltstone, mudstone, carbonaceous mudstone, 
sandstone, and conglomerate (see pl. 1C), the vertical stacking of which appears to be random. The vertical succession includes, in ascending order: (1) a 6.5-ft interval coarsening upward from mudstone to fine-grained sandstone with mostly plane to wavy lamination; (2) a 12-ft interval of interbedded siltstone, mudstone, and carbonaceous mudstone; (3) a 4-ft interval of medium- to coarse-grained sandstone that displays small-scale trough crossbedding at the top; (4) an 11-ft interval of mostly silty mudstone and siltstone with a 2-ft-thick bed of fine-grained sandstone near the middle; (5) a 4-ft interval of pebbly sandstone and granule to pebble (mostly chert clasts) conglomerate (fig. 4) that displays a loaded base, bar-form geometry, and trough crossbedding and contains a conspicuous volume of macerated woody plant fragments; (6) a 6 -ft interval fining upward from current-rippled, fine-grained sandstone to siltstone; (7) a 4-ft interval comprising thin beds of current-rippled, fine-grained sandstone and mudstone; (8) a 4 -ft interval coarsening upward from carbonaceous mudstone through silty mudstone to fine-grained sandstone; and (9) a 5 -ft interval of siltstone. Subtle root traces are present in the lower part of the unit, and macerated woody plant fragments are common throughout. The gamma-ray profile for the unit is serrated, with generally medium to high gamma-ray values adjacent to mudstone and siltstone intervals and low gammaray values adjacent to sandstone intervals (pl. 1).

Interpretation.-We interpret unit $\mathrm{B}$ as the deposits of a coastal plain, with specific subenvironments possibly including crevasse splay (coarsening-upward interval), overbank or flood plain (thin interbedded siltstone and mudstone intervals), marsh (carbonaceous mudstone), and fluvial creek (crossbedded and current-ripple-bedded sandstone). Collectively, the facies within the unit may have been deposited on a low-relief coastal plain in an interfluve position or on a low-lying, distal part of an alluvial fan.

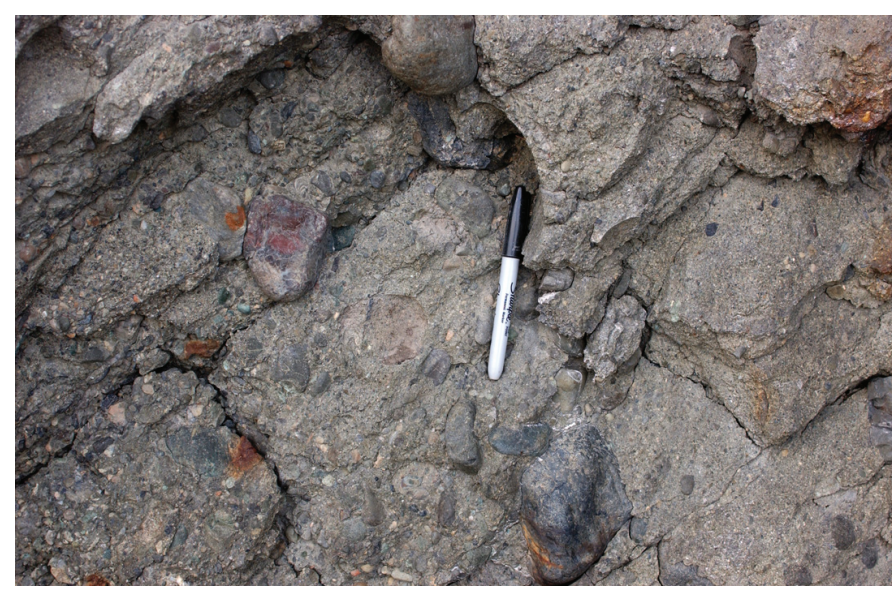

Figure 3. Conglomerate in upper part of unit $A(\sim 40 \mathrm{ft}$ in measured section, pl. 1), showing range of clast sizes, poorly sorted texture, and various colors among chert clasts.

\section{Unit C}

Description.-Unit C, $50 \mathrm{ft}$ thick, consists mostly of sandstone beds punctuated by thin mudstone beds (see pl. 1; fig. 5). The vertical succession includes, in ascending order: (1) a 6-in. interval of granule to pebble (mostly chert clast) conglomerate; (2) a $23-\mathrm{ft}$ interval of thin-bedded ( $<6 \mathrm{in}$. thick), fine- to medium-grained sandstone that displays planeparallel laminations and symmetrical ripples (fig. 6), locally contains vertical trace fossils (Skolithos) and bilobate trails (Gyrochorte?) on bedding surfaces, and includes an upwardincreasing number and thickness of mudstone (some carbonaceous) laminations between sandstone beds; (3) a 6-ft interval of fine-grained sandstone that contains a concentration of large (max $2 \mathrm{ft}$ diam) reddish-gray concretionary clasts at the base, displays large-scale northeastward-vergent flame structures (fig. 7) and contorted laminae in the lower $3 \mathrm{ft}$, includes scattered horizons of pebbles, is mostly massive (structureless), and displays a symmetrical-rippled upper surface; (4) a 4-ft interval of thin-bedded, very fine grained sandstone and siltstone characterized by symmetrical ripples (some that display interference patterns) and common tracks and trails on bedding surfaces, overlain by fine-grained sandstone with thin, plane-parallel lamination that results in flaggy weathering; and (5) a 16.5-ft interval of fine-grained sandstone that contains local concentrations of reddish-gray concretionary clasts, displays a predominance of plane-parallel and hummocky crossstratification, includes 2- to 9-in.-diameter spherical ("cannonball") concretions near the top, and has a distinct oil odor throughout. The gamma-ray profile for the unit is moderately serrated, with generally medium gamma-ray values throughout (pl. 1). The high gamma-ray "spikes" that define the serrated pattern correspond to beds that contain concentrations of thin mudstone laminae between sandstone beds.

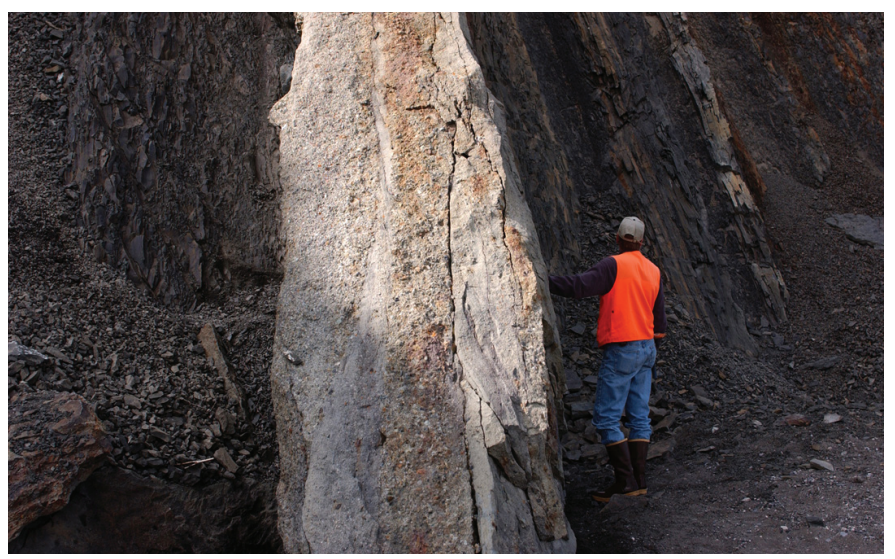

Figure 4. Bed of pebbly sandstone among generally finer grained rock types in unit B ( 80-90 ft in measured section, pl. 1). Stratigraphic facing direction is to right. Note that convex-upward top surface of pebbly sandstone, which defines bar-form geometry, is reflected in thinning of bed from middle to top of photograph. 
Interpretation.-We interpret unit $\mathrm{C}$ as the deposits of a transgressive shoreface and delta front. Interval 1 rests on an erosional surface that separates nonmarine deposits below from marine deposits above. The erosional surface is interpreted as a transgressive surface of ravinement, and the thin conglomerate as a transgressive lag. Interval 2 is interpreted as the deposits of a transgressive shoreface, as suggested by the combination of plane-parallel laminations, wave ripples, Skolithos burrows, and trails on bedding surfaces. The relatively fine grained texture of the sandstone and the predominance of thin beds and plane-parallel laminae suggest that the shoreface was characterized by low to moderate wave energy. In the upper part of this interval, the increasing abundance of thin mudstone beds draped on wave-rippled upper surfaces of sandstone beds indicates that the area was subjected to progressively lower wave energy over time, suggesting either deepening of the shoreface or deposition of this transgressive shoreface in a relatively low energy part of the coastline, possibly a bay or lagoon. Interval 3 rests on a sharp contact that may be an erosional surface. The concretionary clasts are identical to the red-weathering carbon- ate concretions that are common in associated mudstone beds throughout the Brookian sequence (see subsequent sections), and the flame structures and contorted laminae suggest rapid deposition of water-saturated sediment. These characteristics, together with the inferred depositional facies of underlying and overlying strata, suggest deposition in a delta front, where rapid deposition of sediment that included intraformational constituents (concretionary clasts) would be common. Interval 4 is interpreted as a return to wavedominated shoreface sedimentation, similar to the conditions under which interval 2 was deposited. Interval 5 is interpreted as the deposits of an upward-deepening shoreface, possibly a delta front. The predominance of plane-parallel and hummocky cross-stratification suggests deposition in a wave-dominated environment partly above and partly below fairweather wave base. The common occurrence of pebble concentrations, which define the bases of many beds in this interval, may reflect either pulses of fluvial discharge from a delta or pulses of higher wave energy during storms. Overall, we interpret unit $\mathrm{C}$ as the deposits of a transgressive shoreface, probably in proximity to an ephemeral delta. Most

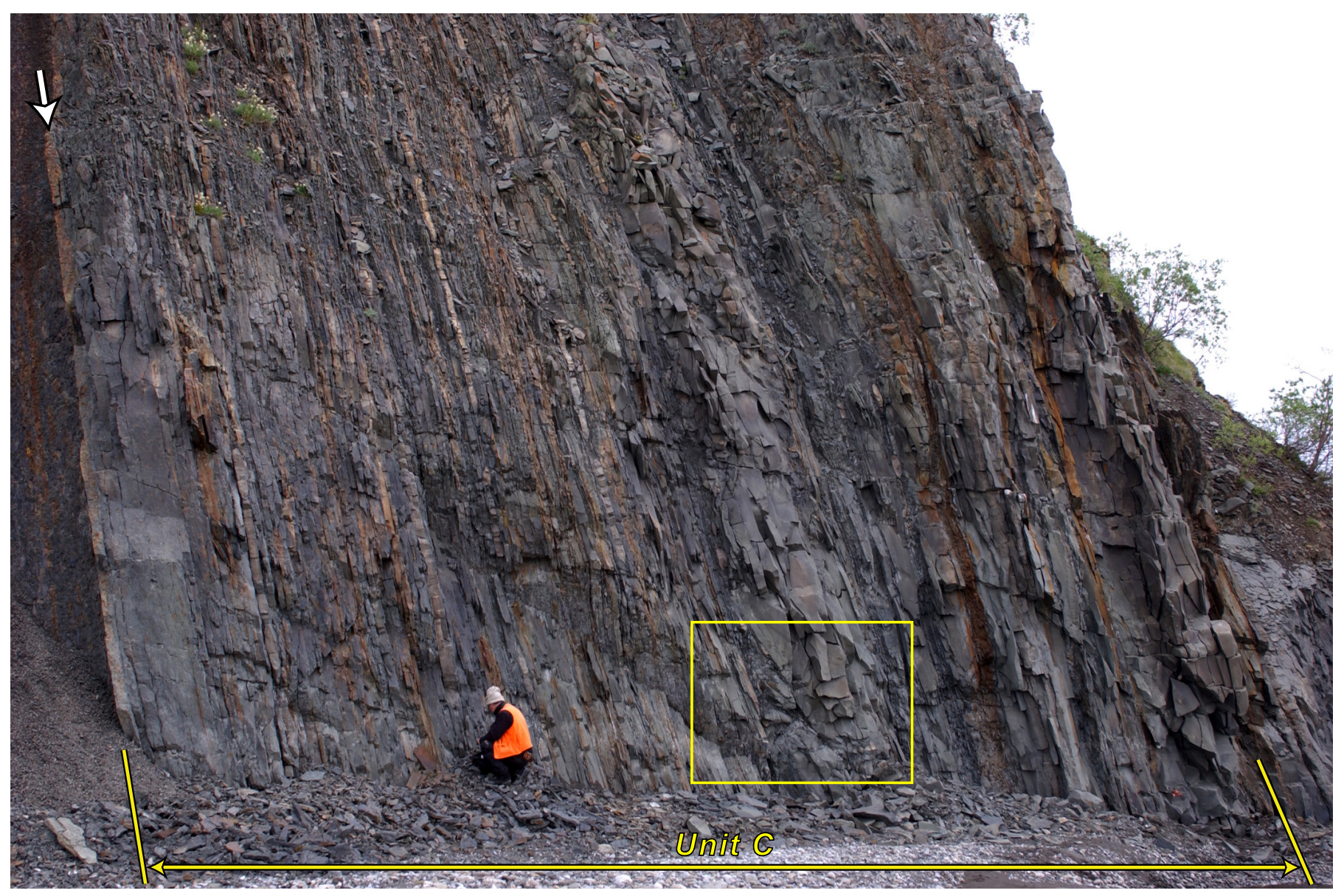

Figure 5. Unit C ( 105-160 ft in measured section, pl. 1), showing thin transgressive pebble lag (white arrow) resting on erosive contact inferred to represent ravinement surface. Stratigraphic facing direction is to right. Yellow rectangle shows area of figure 7. 
significantly, the unit represents a transition between nonmarine deposits below and marine deposits above.

\section{Unit D}

Description.-Unit D, as much as $6 \mathrm{ft}$ thick, comprises a laterally stacked (shingled) assemblage that includes conglomerate, sandstone, and siltstone (see pl. 1; fig. 8). The conglomerate beds are lenticular, most displaying convex-downward bases (that is, troughs) and some displaying convex-upward tops. The granule to pebble conglomerate is poorly sorted and contains both angular and rounded clasts of chert, tuffaceous chert, and light-colored (salt and pepper) sandstone (fig. 9) in a matrix of muddy sandstone. The sandstone beds are dark green-gray and display pebbles similar to the clasts in the

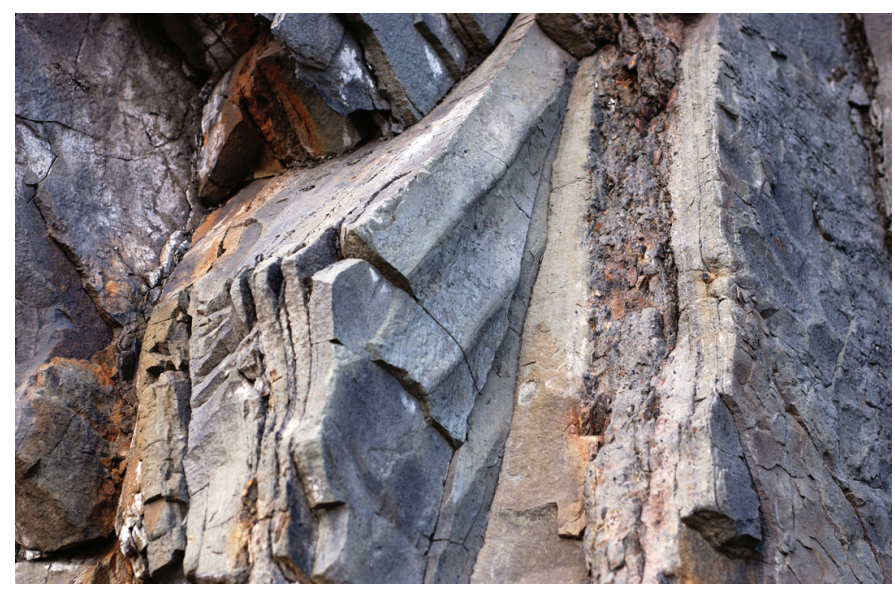

Figure 6. Bedding surfaces in lower part of unit $C(\sim 125 \mathrm{ft}$ in measured section, pl. 1), showing straight-crested wave ripples (center) and apparent interference ripples (right). Area of photograph is $\sim 2 \mathrm{ft}$ wide.

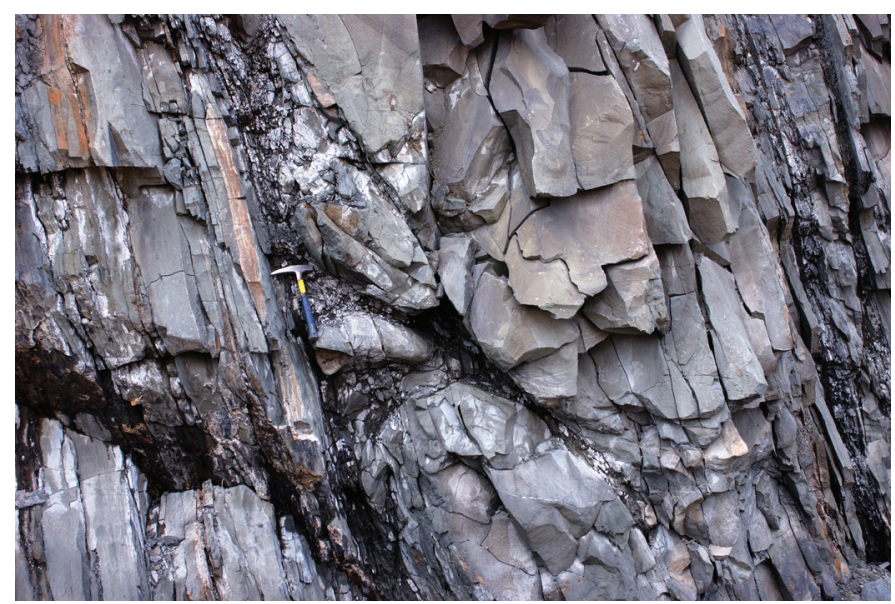

Figure 7. Large flame structure extending from base of a thick bed near middle of unit C (pl. 1; see fig. 5 for location). Stratigraphic facing direction is to right. conglomerate beds (fig. 9). The siltstone beds contain chert pebbles and pebble- to cobble-size clasts of coaly plant fragments. Many upper bedding surfaces of all rock types display symmetrical-ripple bedforms.

Interpretation. - A unique interpretation for the origin of unit D is difficult. Most of its attributes suggest deposition by fluvial or debris-flow processes, similar to those inferred for unit A. However, the modest thickness of unit D, its stratigraphic position between deposits of definite marine origin, and the presence of wave-rippled bedding surfaces throughout suggest deposition in a marine-influenced setting. In the light of these observations, we interpret unit $\mathrm{D}$ as a pulse of fluvial sedimentation (probably a fluvial flood event) into a delta-front environment. Thus, the unit represents a thin fluvial signature in an overall succession of upward-deepening shoreface deposits.

\section{Unit $\mathrm{E}$}

Description. - Unit E, $\sim 40 \mathrm{ft}$ thick, comprises a finingupward interval of sandstone, siltstone, and mudstone (see pl. 1; fig. 8). The lower $23 \mathrm{ft}$ consists of dark-green-gray, finegrained sandstone that appears to be mostly massive (lacking clearly defined bedding) and commonly is mottled. Randomly oriented macerated plant fragments are common throughout. Locally, crudely defined bedding surfaces display the trace fossil Rhizocorallium. Oil odor is common on freshly broken surfaces of sandstone throughout much of the unit. The upper $17 \mathrm{ft}$ consists of fine-grained sandstone through siltstone to mudstone. Throughout the gradation, the unit remains dark green-gray to dark gray in color and is mottled to massive. The top of the unit is arbitrarily placed at the base of the clearly defined fault zone described previously (pl. 1). Molds and casts of small, epifaunal bivalves and one larger bivalve (fig. 10) are present near the middle of the unit. A solitary belemnite (fig. 11) was obtained from the upper part of the unit, near the middle of the fining-upward interval (pl. 1).

Interpretation.-We interpret unit $\mathrm{E}$ as the deposits of an upward-deepening shoreface. Although distinct trace fossils are relatively rare, the mottling to massiveness of the rocks and the local presence of well-preserved Rhizocorallium suggest that the sediment was thoroughly bioturbated. Megafossils support an interpretation of deposition in a shallow-marine setting characterized by occasional turbulence. The upper part of the unit, which approximates the boundary between predominately sandstone below and predominately mudstone above, corresponds to a transition from lower shoreface to offshore, in the terminology of Walker and Plint (1992).

\section{Fault Zone and Contact Between the Fortress Mountain and Torok Formations}

The fault zone discussed previously occurs between 200 and $210 \mathrm{ft}$ in the Siksikpuk River section (see pl. 1; fig. 1). An estimated $250 \mathrm{ft}$ of strata is "missing" from the measured section across the resulting fault gap. Rocks that occupy the 


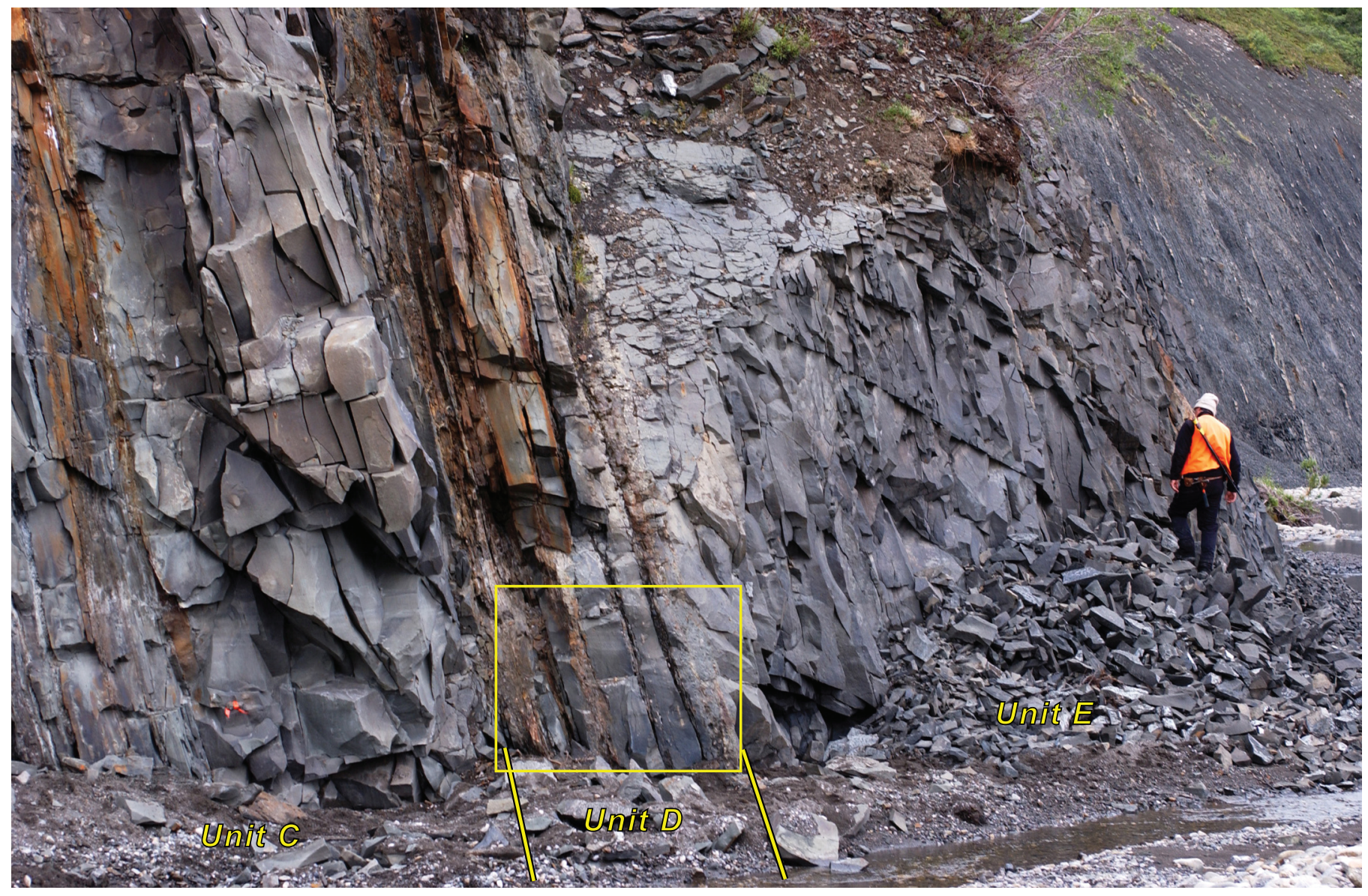

Figure 8. Upper part of unit $\mathrm{C}$, unit $\mathrm{D}$, and lower part of unit $\mathrm{E}(\sim 155-180 \mathrm{ft}$ in measured section, pl. 1). Stratigraphic facing direction is to right. Yellow rectangle shows area of figure 9 .

gap in the measured section are visible in the upper part of the bluff on the hanging wall of the fault (pl. 1C). Although these strata are not easily accessible, they appear to be composed of medium- to dark-gray mudstone and siltstone with thin interbeds of sandstone, similar to rocks in the upper part of unit $\mathrm{E}$ and throughout unit $\mathrm{F}$.

The contact between the Fortress Mountain and the Torok Formations is placed at the base of this fault zone because that horizon represents the boundary between mostly sandstone and conglomerate below and mostly mudstone above. Thus, this horizon represents the most likely candidate for a regionally mappable contact between the two formations.

\section{Torok Formation}

\section{Unit F}

Description.—Unit F, $\sim 100 \mathrm{ft}$ thick, consists mostly of silty mudstone and siltstone with thin interbeds of sandstone

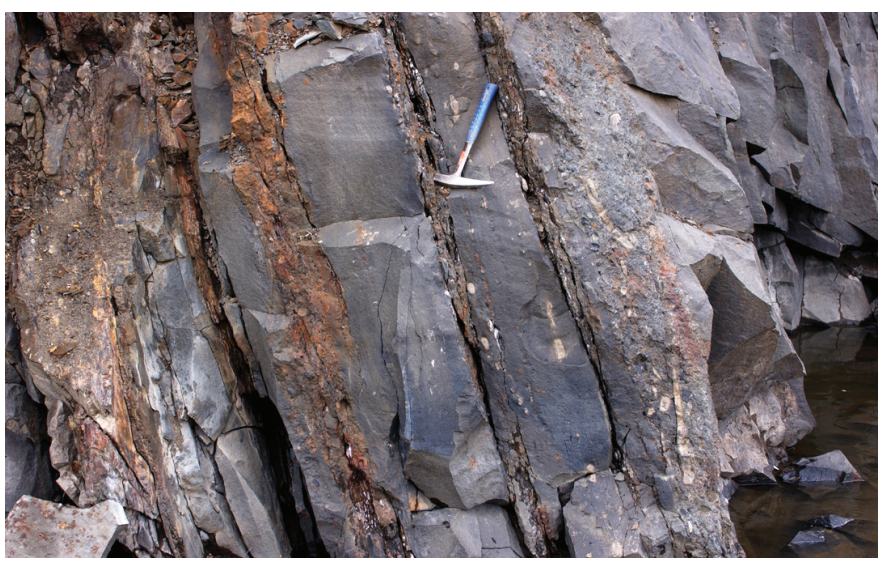

Figure 9. Heterogeneous conglomerate, sandstone, and siltstone bed in unit D (pl. 1; see fig. 8 for location). Light-colored clasts, including large elongate angular clasts at right, are composed of sandstone; most dark clasts are composed of chert. Stratigraphic facing direction is to right. 
and numerous concretionary beds and lenses (see pl. 1). Most of the unit is composed of medium- to dark-gray mudstone containing silt and very fine grained sand that vary in abundance with stratigraphic position. The weathering pattern of the outcrop reflects this subtle variation: muddy intervals are relatively recessive, and silty and sandy intervals are slightly more resistant. Bedding ranges from indistinct horizontal laminae defined by fraction-of-an-inch-thick silt layers to nearly structureless mudstone that lacks lamination. Light-colored beds and broad lenses of calcareous concretions, most 0.5 to 1 $\mathrm{ft}$ thick, are the most resistant parts of the unit. Most of these concretionary beds and lenses are hosted by siltstone or very fine grained sandstone beds, which occur throughout the unit. The sandstone beds display plane-parallel laminations and small-scale hummocky cross-stratification (fig. 12).

Interpretation.-We interpret unit $\mathrm{F}$ as offshore deposits, probably grading upward from proximal shelf to midshelf (Walker and Plint, 1992), on the basis of overall lithology, the inferred facies of underlying and overlying units, and the

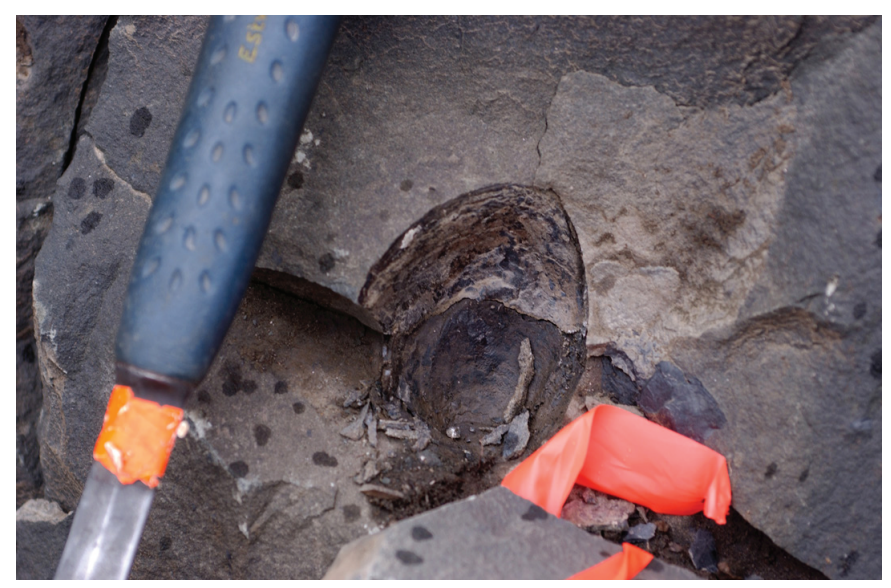

Figure 10. Mold of large bivalve (Arctica) in lower part of unit $\mathrm{E}$ (178 ft in measured section, pl. 1).

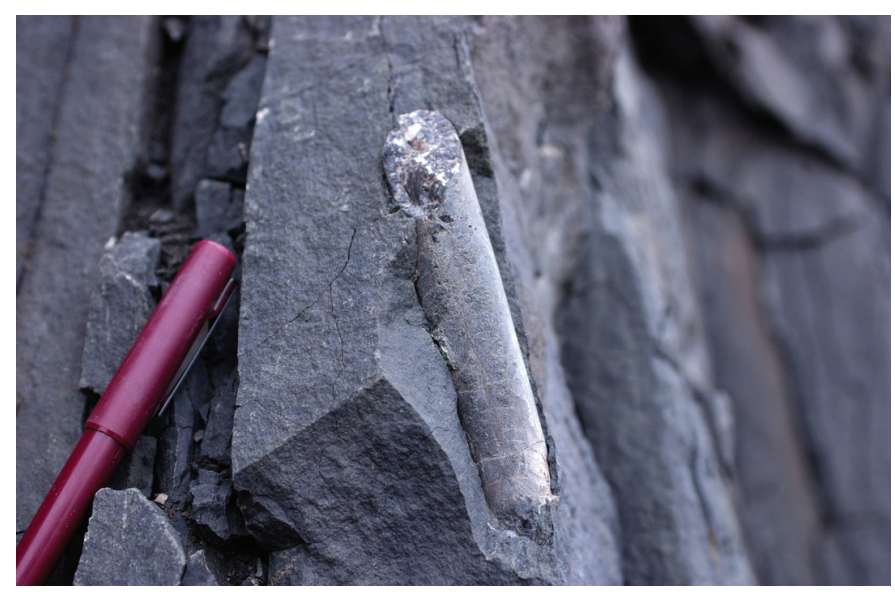

Figure 11. Cast of belemnite (Acroteuthis sp. aff. A. conoides Swinnerton) in upper part of unit $\mathrm{E}$ (189 ft in measured section, pl. 1). presence of hummocky cross-stratified sandstone beds, which suggest occasional water depths above storm-wave base. Although neither body fossils nor distinct trace fossils were observed in the unit, the structurelessness of much of the mudstone probably indicates bioturbation.

\section{Unit G}

Description.-Unit G, $290 \mathrm{ft}$ thick, consists mostly of dark-gray mudstone containing silt and very fine grained sand that vary in abundance with stratigraphic position (see pl. 1; fig. 13). Though generally similar lithologically to unit $\mathrm{F}$, unit $\mathrm{G}$ is notably finer grained overall. Bedding is generally indistinct horizontal lamination and nearly massive mudstone that lacks lamination. Light-colored calcareous concretions are common throughout the unit (fig. 13). In contrast to unit F, the concretions in unit $\mathrm{G}$ are mostly ovoid and only 1.5 to $3 \mathrm{ft}$ long. Most concretions are not nucleated in siltstone or sandstone beds as in unit F. Very fine grained sandstone beds occur
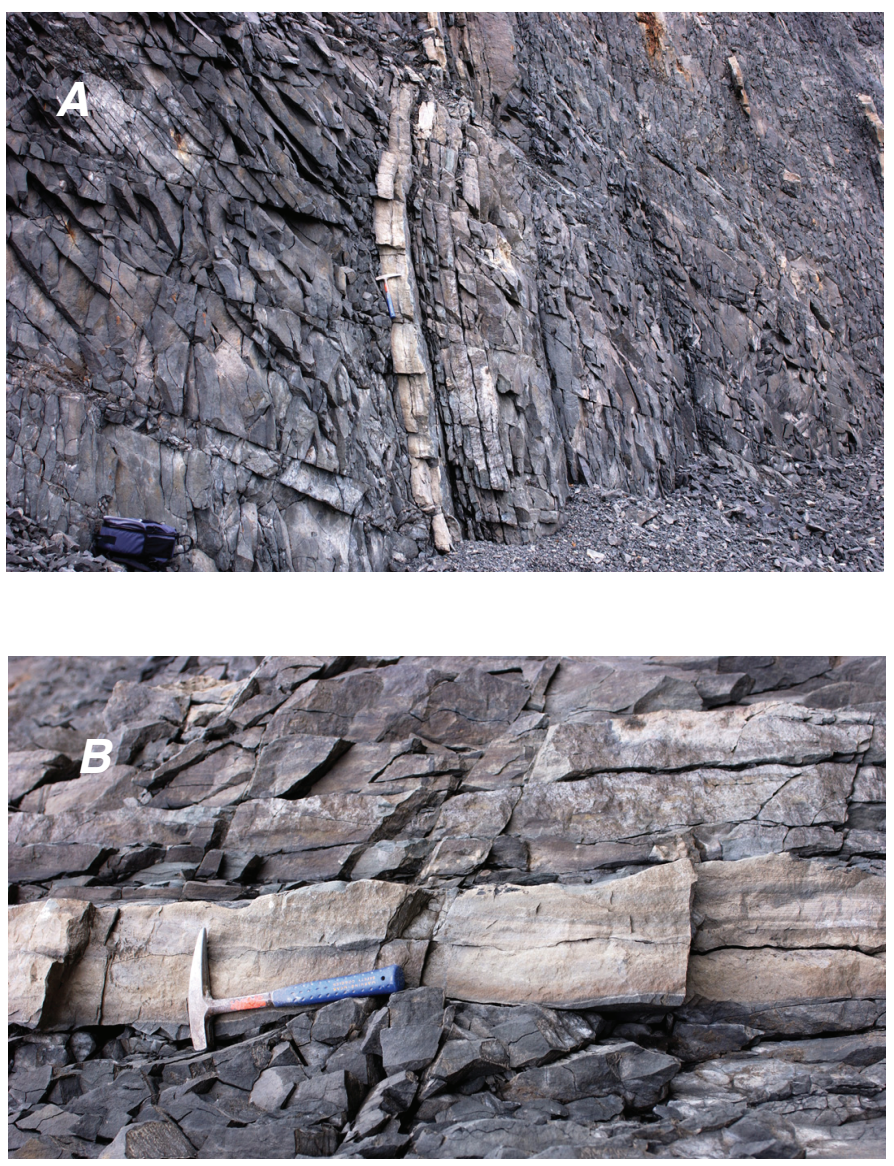

Figure 12. Lower part of unit $\mathrm{F}(\sim 220 \mathrm{ft}$ in measured section, pl. 1). A, Light-colored calcareous concretionary bed hosted by very fine grained sandstone in dark silty mudstone. Stratigraphic facing direction is to right. $B$, Closeup of sandstone bed, showing wave-rippled upper surface and small-scale hummocky crossstratification. Stratigraphic facing direction is toward top of photograph. Hammer is at same location in figures $12 A$ and $12 B$. 
but are less abundant than in unit F. The sandstone beds mostly display plane-parallel laminations, and a few beds display subtle hummocky cross-stratification. Four samples submitted for biostratigraphic analysis yielded foraminifers interpreted to represent environments ranging from outer neritic to lower bathyal (pl. 1).

Interpretation.-We interpret unit $\mathrm{G}$ as the deposits of a progressively deepening distal offshore shelf to slope environment, mostly on the basis of the gradational facies relation with underlying units, the inferred origin of overlying units, the predominance of mudstone with few sandstone interbeds, and paleoenvironmental inferences from foraminifers. Although neither body fossils nor distinct trace fossils were observed in the unit, the massiveness of much of the mudstone probably indicates bioturbation.

\section{Unit H}

Description.-Unit $\mathrm{H}, \sim 10 \mathrm{ft}$ thick, consists of orangeweathering, fine-grained sandstone (see pl. 1). Neither the base nor the top of the unit is exposed; however, the distribution of sandstone on outcrop suggests a convex-downward base and a relatively flat top (pl. 1D). No beds or sedimentary structures are discernible within the unit because it is fractured and deeply weathered. In places, relatively unweathered mediumgray sandstone is visible. Oil odor is evident on freshly broken surfaces of sandstone throughout the unit.

Interpretation.-We interpret unit $\mathrm{H}$ as the deposits of a turbidite slope channel on the basis of its general similarity to the sandstone beds higher in the section (see below) and its dissimilarity to the sandstone beds in underlying units. The base of unit $\mathrm{H}$ is interpreted as a significant erosional surface that separates shelf facies below from marine-slope facies above; the significance of this erosional surface is discussed below.

\section{Unit I}

Description.-Unit I, $\sim 100 \mathrm{ft}$ thick, consists of silty mudstone with a few thin $(<1 \mathrm{ft}$ thick) sandstone beds (see pl. 1). The mudstone is poorly exposed because of talus cover, but it appears to be horizontally laminated. The finegrained sandstone beds also are poorly exposed, and no sedimentary structures were observed. Two samples submit-

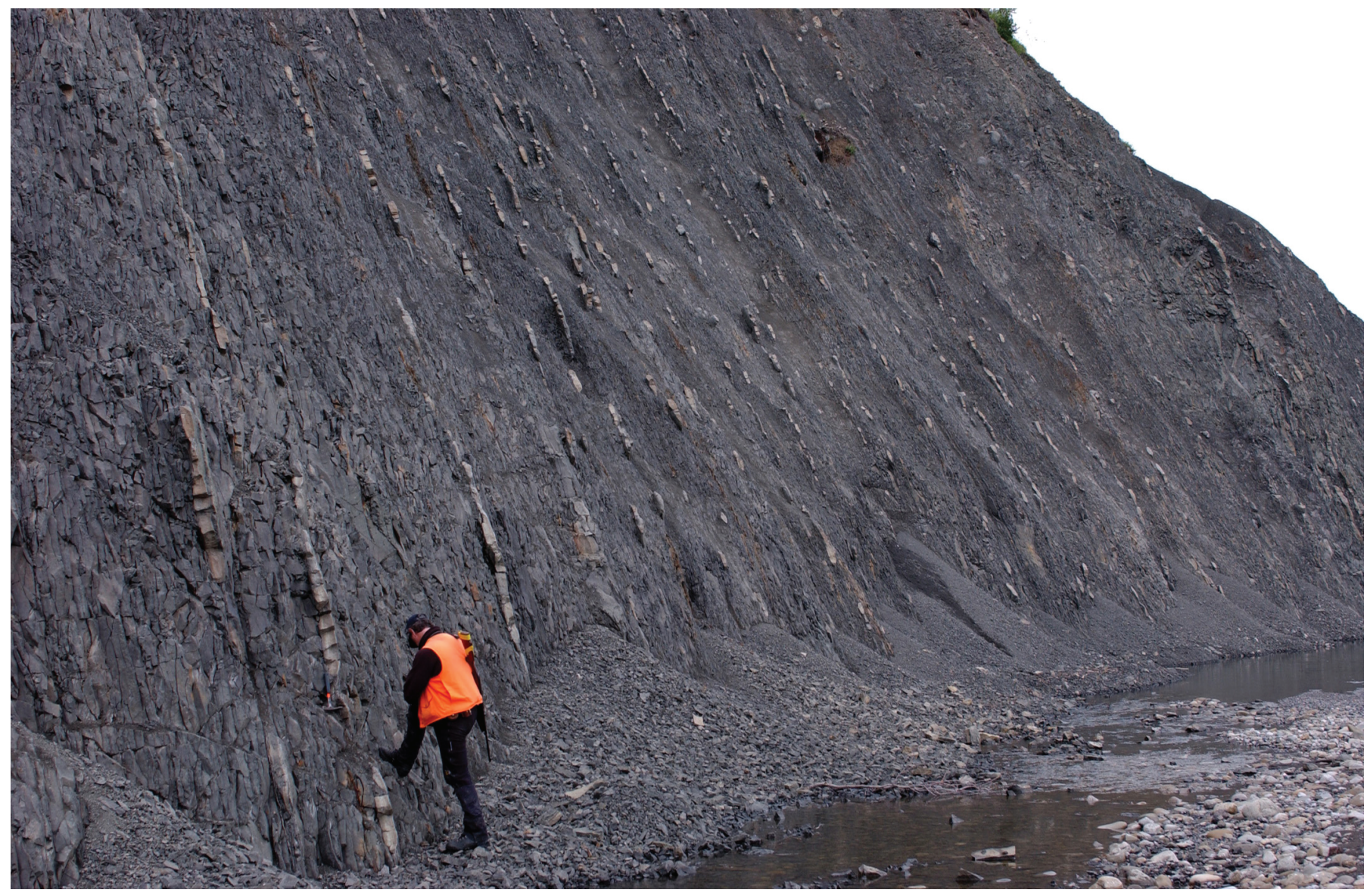

Figure 13. Lower part of unit $\mathrm{G}(\sim 350 \mathrm{ft}$ in measured section, pl. 1), showing medium- to dark-gray silty mudstone punctuated by horizons of laterally discontinuous calcareous concretions. Stratigraphic facing direction is to right. 
ted for biostratigraphic analysis yielded foraminifers interpreted to represent environments ranging from outer neritic to middle bathyal (pl. 1).

Interpretation.-We interpret unit I as the deposits of a marine slope, primarily on the basis of stratigraphic succession, lithology, and paleoenvironmental inferences from foraminifers.

\section{Unit J}

Description.-Unit J, as much as 1,100 ft thick, consists of dark-gray fissile shale and mudstone with thin interbeds of sandstone (see pl. 1; fig. 14). The base of the unit is not exposed, but distinct changes in color and lithology relative to underlying unit I are evident on outcrop (see pl. 1). A thick interval included in unit $J$ falls within the 750-ft gap in the measured section (pl. 1), where the outcrop is covered by talus and vegetation. The upper part of the unit is well exposed. Among the mudstone beds described in the entire Siksikpuk River section (fig. 1), unit $\mathrm{J}$ is unique in that it is less silty and more fissile, as well as in terms of structural deformation, because it displays varying dips and overturned beds (pl. 1), suggesting that the unit may be structurally thickened. Thin (mostly $<6$ in. thick) sandstone beds occur locally in the unit (fig. 14). The sandstone is very fine grained to fine grained and greenish gray in color. Current ripples and ripple-drift cross-stratification are visible in some beds. The unit also contains common calcareous concretions concentrated parallel to bedding. Four samples submitted for biostratigraphic analysis yielded foraminifers interpreted to represent environments ranging from middle to lower bathyal (pl. 1).

Interpretation.-We interpret unit $\mathrm{J}$ as the deposits of a marine slope, primarily on the basis of stratigraphic succession, lithology, and paleoenvironmental inferences from foraminifers. The finer grained texture and greater fissility of the unit suggest that it is a transgressive-slope deposit (see next section).

\section{Unit K}

Description.-Unit K, $52 \mathrm{ft}$ thick, includes conglomerate, mudstone, and sandstone beds (see pl. 1E). The vertical succession includes, in ascending order: (1) a 1-ft interval of matrix-supported conglomerate with chert clasts (max 1.5 in. diam) in a fine- to medium-grained sandstone matrix; (2) a 10-ft interval of medium-gray silty shale with spherical calcareous concretions (2-4 in. diam); (3) a 1-ft interval of spherical to ovoid calcareous concretions (2-4 in. diam) concentrated in a matrix of swirled mudstone (fig. 15); (4) a 5-ft interval of massive (structureless) silty mudstone with floating chert pebbles (max 1.5 in. diam); (5) a 4-ft interval of matrix-supported conglomerate with chert clasts ( $\max 2 \mathrm{in}$. diam) in a matrix of sandy, silty mudstone; (6) a 16-ft interval of mudstone with randomly scattered chert clasts ( $\max 3 \mathrm{in}$. diam); (7) a channel-shaped bed (max $13 \mathrm{ft}$ thick) of matrixsupported conglomerate with rounded chert clasts ( $\max 3$ in. diam) and angular sandstone, conglomerate, and mudstone clasts (max $3 \mathrm{ft}$ diam) in a matrix of muddy sandstone; and (8) a 2-ft interval of sandstone that fines upward from coarse to fine grained, displays a broad channel geometry, and contains current ripples at the top. Sticky bitumen occurs on broken surfaces of many concretionary clasts in interval 3 , and oil odor is evident on freshly broken surfaces of clasts and the sandstone matrix throughout interval 7.

Interpretation.-We interpret unit $\mathrm{K}$ as the deposits of a composite slope channel. Most beds in the unit consist of either sand- or mud-supported conglomerate, suggesting deposition by high-density gravity flows (Lowe, 1982). The base of unit $\mathrm{K}$ is interpreted as the erosive base of a slope channel, on the basis of the marked lithologic contrast between beds below and above; this surface may be a higher-order sequence boundary (see subsequent section). The heterolithicity of the beds in unit $\mathrm{K}$ suggests that the slope channel was filled by multiple depositional events spanning a range of

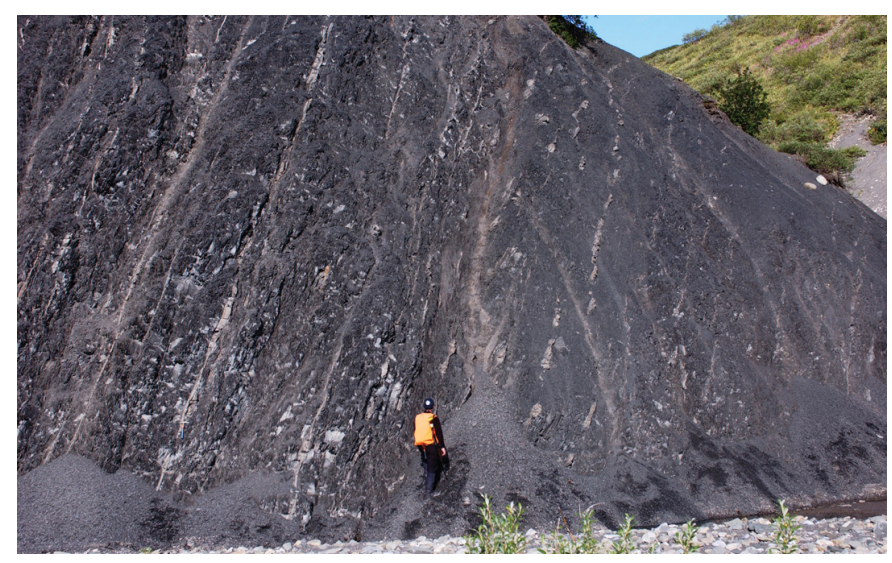

Figure 14. Unit J ( 850 ft in measured section, pl. 1), showing dark-gray fissile shale punctuated by thin sandstone beds. Stratigraphic facing direction is to right. Beds are overturned.

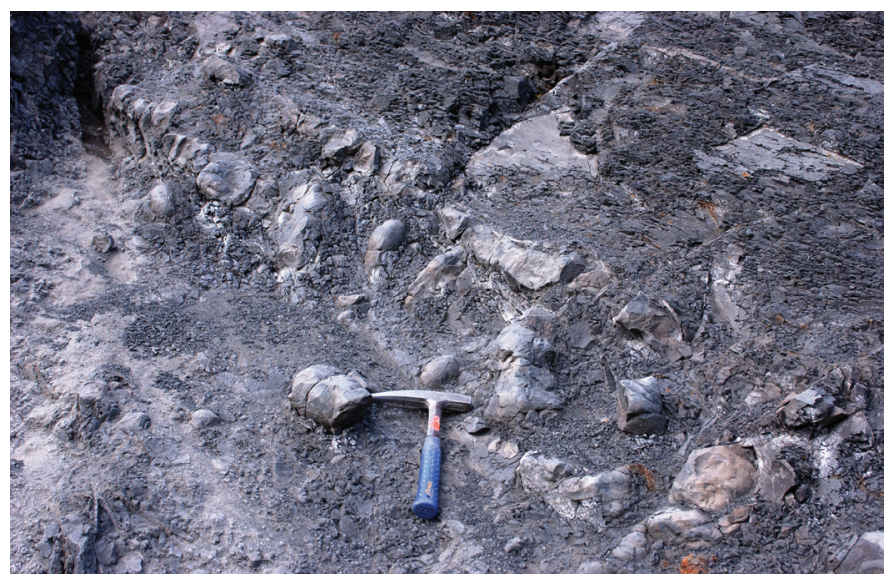

Figure 15. Lower part of unit $\mathrm{K}(1,727 \mathrm{ft}$ in measured section, $\mathrm{pl}$. 1), showing calcareous concretions concentrated in a matrix of swirled mudstone. Sticky bitumen is present on broken surfaces of many concretions. Stratigraphic facing direction is to upper right. 
flow characteristics, including high-density, sand-dominated flows (intervals 1 and 7), muddy debris flows (intervals 3, 4, and 6), and high-density, mixed sandy-muddy flows (interval 5) (Lowe, 1982). The uppermost interval (8), which was probably deposited as a low-density turbidite (Lowe, 1982), may represent the waning part of the flow that deposited the underlying conglomerate (interval 7). The clast composition of the unit indicates a mixture from extrabasinal and intraformational sources. Most clasts are composed of chert derived from extrabasinal sources; however, some beds contain abundant intraformational clasts, including calcareous concretions and angular blocks of sandstone, conglomerate, and mudstone. These intraformational clasts were evidently derived by erosion of unconsolidated or poorly consolidated sediment during incision of the slope and (or) shelf margin.

\section{Unit L}

Description.-Unit L, $660 \mathrm{ft}$ thick, consists of silty mudstone facies that extends from the top of unit $\mathrm{K}$ to the top of the measured section (see pl. 1). Unit L displays similar lithologic characteristics throughout and herein is considered a single facies. The lower $372 \mathrm{ft}$ of the unit is a vertically continuous exposure of silty mudstone. Throughout the rest of the measured section (above 2,145 ft, pl. 1), unit L is interbedded with sandstone units ( $\mathrm{M}$ through $\mathrm{Q}$ ), each of which is described below. Unit $\mathrm{L}$ is composed of silty mudstone with rare thin $(<1$ $\mathrm{ft}$ thick) sandstone beds and common calcareous concretions. The mudstone ranges in bedding from horizontally laminated to nearly massive (no visible lamination). Concretions range from 3 to $6 \mathrm{in}$. in thickness and from 0.5 to $3 \mathrm{ft}$ in width. One sample submitted for biostratigraphic analysis yielded foraminifers interpreted to represent a bathyal environment (pl. 1).

Interpretation.-We interpret unit $\mathrm{L}$ as the deposits of a marine slope, primarily on the basis of stratigraphic succession, lithology, relation to interbedded sandstone, and paleoenvironmental inferences from foraminifers. The range in bedding from horizontally laminated to nearly massive may reflect sparse to thorough bioturbation, respectively.

\section{Unit M}

Description.-Unit M, $10 \mathrm{ft}$ thick, consists of sandstone and mudstone (see pl. 1). The base of the unit is sharp and apparently erosive into underlying mudstone. Near river level, the unit consists mostly of dark-greengray, fine-grained sandstone beds, 0.5 to $3 \mathrm{ft}$ thick, that are horizontally laminated to massive (structureless) and display subtle fining-upward trends. Individual sandstone beds are separated by thin ( $<6$ in. thick) mudstone interbeds in some places and amalgamated in other places. Observed from a distance, the sandstone beds thin and gently dip laterally toward a channel-shaped incision (pl. 1F) that is filled by $5 \mathrm{ft}$ of mudstone, overlain by a 2 -ft-thick bed that fines upward from cobble and pebble conglomer- ate, through coarse-grained sandstone, to vitrain-rich, finegrained sandstone. Oil odor is evident on freshly broken surfaces of sandstone throughout the unit.

Interpretation.-We interpret unit $\mathrm{M}$ as the deposits of a slope channel composed mostly of low-density turbidites. The lateral thinning and gentle dip of sandstone beds indicates that the channel was sinuous (meandering). The channelshaped incision appears to be an abandoned thalweg of the sinuous slope channel, and the fining-upward, conglomerateto-sandstone bed probably is a high-density turbidite that was localized in the previously abandoned channel.

Unit N

Description.-Unit N, 10 to $24 \mathrm{ft}$ thick, consists mostly of sandstone (see pl. 1). At the top of the bluff, the unit is $10 \mathrm{ft}$ thick and consists of sandstone beds, each 0.5 to $1 \mathrm{ft}$ thick, with thin ( $<3$ in. thick) mudstone interbeds. The unit thickens laterally toward river level, generally displaying a channel geometry, but abruptly thickens across a fault at one site near the top of the bluff (pl. 1G). At river level, the unit consists of $24 \mathrm{ft}$ of dark-green-gray, fine-grained sandstone that ranges in bedding from horizontally laminated to massive (structureless) (fig. 16). At river level, the sandstone is separated into bed sets, each 1 to $8 \mathrm{ft}$ thick, by thin (3-6 in. thick) interbeds of siltstone and silty mudstone. Individual bed sets are composed of amalgamated sandstone beds, 6 to 18 in. thick, as evidenced by subtle contacts defined by concentrations of woody plant debris and mud ripup clasts. A channel-shaped incision, $6 \mathrm{ft}$ deep by $>50 \mathrm{ft}$ wide, filled with silty mudstone occurs in the lower part of the bluff (pl. $1 G)$. Strong oil odor is evident on freshly broken surfaces of sandstone throughout the unit.

Interpretation.-We interpret unit $\mathrm{N}$ as the deposits of a slope channel composed of both low- and high-density turbidites. The unit thickens and becomes more massive toward river level, suggesting that the exposed part represents the lateral flank of a turbidite channel. The turbidite beds and mudstone interbeds near the upper part of the bluff may represent vertically accreted, low-density deposits near the channel margin (gradational to or representing levee deposits), whereas the thicker, amalgamated beds near river level may represent deposits of high-density turbidites near the channel thalweg. The abrupt increase in thickness of the unit across a fault suggests syndepositional fault movement, possibly caused by mass movement (sliding) on an unstable depositional slope. The mudstone-filled channel at the top of the unit is interpreted as abandonment of a late phase of the slope channel.

\section{Unit 0}

Description.-Unit O, 1 to $41 \mathrm{ft}$ thick, consists mostly of sandstone (see pl. 1). Near river level, where the unit is thickest, the lower $6 \mathrm{ft}$ is a mudstone block that has been rotated $20-30^{\circ}$ relative to bedding in the laterally equiva- 
lent unit L. The rotated block clearly is truncated by the overlying sandstone. The overlying $41 \mathrm{ft}$ consists mostly of thin-bedded (1-8 in. thick), fine-grained sandstone with thin ( $<3$ in. thick) interbeds of silty mudstone; a few thicker (2-3 $\mathrm{ft}$ ) interbeds of amalgamated, fine-grained sandstone also occur. The entire thin-bedded interval pinches out laterally, and a mudstone interval (part of unit L) is visible at laterally equivalent levels higher on the bluff (pl. 1H); however, the relation between the sandstone and mudstone is uncertain because much of this interval is covered by talus. Faint oil odor is evident on freshly broken surfaces of sandstone throughout this interval.

Interpretation.-We interpret unit $\mathrm{O}$ as the deposits of a slope-channel composed mostly of low-density turbidites and, possibly, levee facies. The rotated mudstone block at the base of the unit is interpreted as a block of unit $\mathrm{L}$ that slumped into the lower part of the incised channel. The overlying 41 $\mathrm{ft}$ is difficult to interpret because of poor exposure; however, the abrupt lateral pinchout and position above an erosionally truncated slump block of mudstone suggest deposition in an incised channel. Deposition by low-density turbidites and from suspension is inferred from the fine grain size, thin bedding, and presence of mudstone interbeds. Together, these observations suggest deposition in an incised slope channel during or after bypass of the main parts of turbidite flows; thus, this area may represent a channel margin where deposition was mainly from the upper parts of turbidite plumes or from overbank flows that built levee deposits.

\section{Unit P}

Description._Unit P, $23 \mathrm{ft}$ thick at river level, consists of medium-grained sandstone in amalgamated beds, each 1 to $3 \mathrm{ft}$ thick (see pl. 1). Individual beds are defined by concentrations of mudstone ripups or carbonaceous plant debris; the beds are mostly massive (structureless) internally, although subtle convolute laminations are locally visible. The medium-grained sandstone thins abruptly upbluff, and

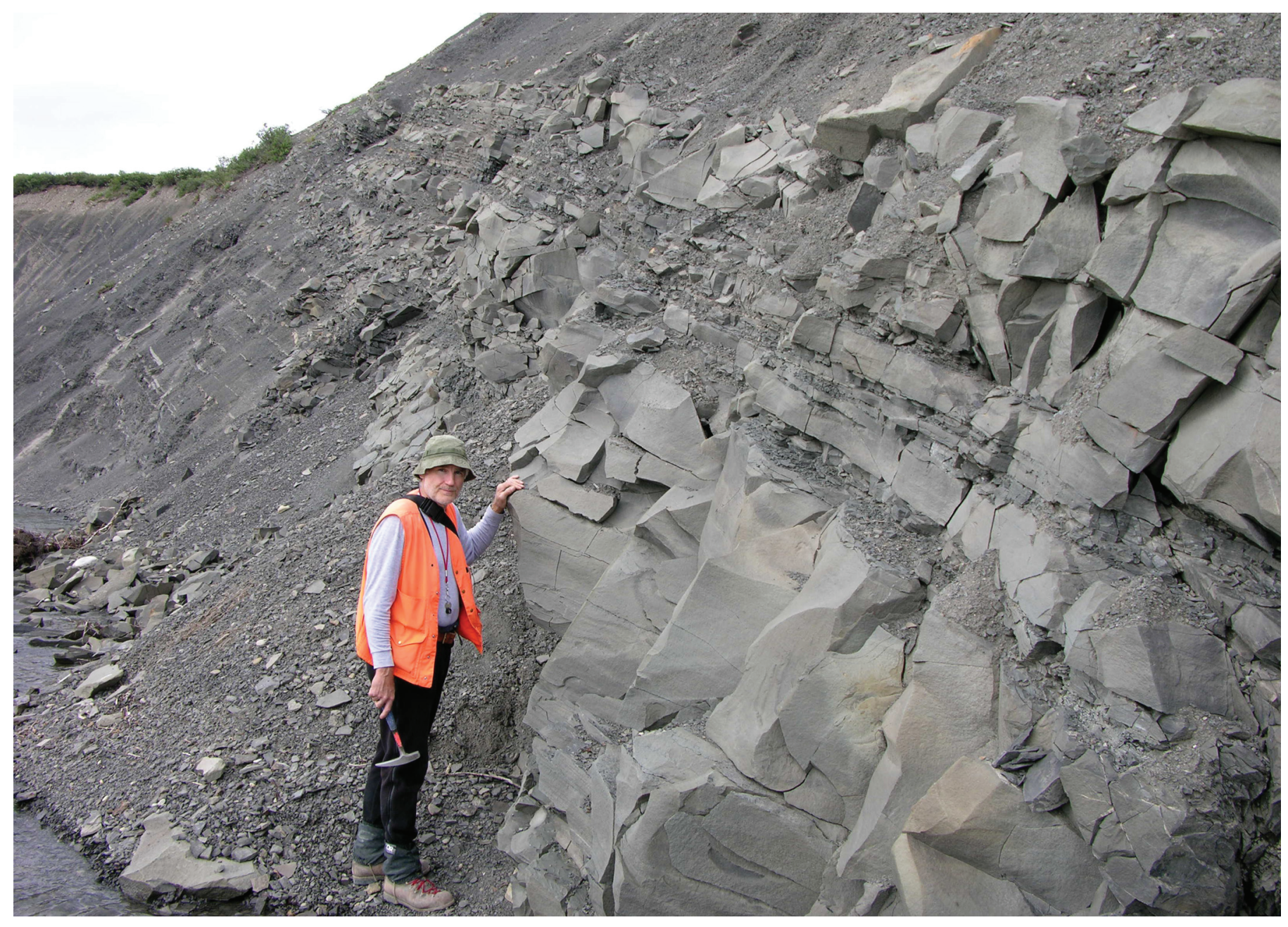

Figure 16. Channelized sandstone in unit N (2,200 ft in measured section, pl. 1). Sandstone thins drastically, and upper half of sandstone grades from relatively massive to relatively thin bedded into distance. 
a single 1-ft-thick sandstone bed occurs near the top of the bluff (pl. 1H). Oil odor is evident on freshly broken surfaces of sandstone throughout the unit.

Interpretation.-We interpret unit $\mathrm{P}$ as the deposits of high-density turbidites in an active slope channel. The medium grain size and amalgamated beds suggest deposition from the main body of a waning turbidite. At the thinnest part of the unit, the single 1-ft-thick sandstone bed is interpreted as an unconfined, low-density turbidite deposited in an overbank setting.

\section{Unit 0}

Description.-Unit Q, $51 \mathrm{ft}$ thick, consists of a lower interval of mostly sandstone overlain by an upper interval that fines upward from sandstone to mudstone (see pl. 1). The lower interval, $33 \mathrm{ft}$ thick, consists of green-gray, fine- to medium-grained sandstone. The lower half of this interval consists of amalgamated beds, 1 to $5 \mathrm{ft}$ thick, of massive sandstone that each grade upward subtly from medium to fine or very fine grained. Mudstone ripup clasts are commonly present, and chert pebble lags are locally present at the base of beds. The upper half of this interval consists of generally thinner (1-2 ft thick) sandstone beds separated by thin (2-3 in. thick) interbeds of silty mudstone. Strong oil odor is evident on freshly broken surfaces throughout this interval. The upper interval, $18 \mathrm{ft}$ thick, fines upward from mostly sandstone to mostly mudstone. The lower part of this interval consists of sandstone beds, 6 to 18 in thick, separated by thin (3-6 in. thick) interbeds of siltstone and silty mudstone. The sandstone beds have sharp bases with flute marks and mostly grade upward from fine to very fine grained. The sandstone beds decrease in abundance and thickness upward through this interval, the upper part of which consists mostly of siltstone and silty mudstone with thin ( $<6$ in. thick) sandstone interbeds. Faint oil odor is evident on broken surfaces of sandstone throughout this interval.

Interpretation.-We interpret unit $\mathrm{Q}$ as the deposits of a slope channel composed of turbidites. The lower interval represents active channel filling by high-density turbidites, whereas the upper interval represents gradual abandonment of the channel and deposition by low-density turbidites.

\section{Sequence Stratigraphy}

\section{Relative Sea Level}

The facies interpretations presented above were used to construct a relative-sea-level curve (fig. 17) that provides a basis for considering the sequence stratigraphy of the Siksikpuk River section (see pl. 1; fig. 1). Below the base of the measured section, a significant drop in relative sea level is inferred (dotted portion of curve, fig. 17) on the basis of obser- vations that (1) the Torok Formation underlying the Fortress Mountain Formation comprises marine-slope facies in nearby outcrops (fig. 1) and (2) unit A was deposited in the proximal reaches of a nonmarine environment. Relative sea level is inferred to have remained low during deposition of unit A.

Unit B, comprising a spectrum of relatively low energy, coastal-plain facies that are inferred to be retrogradational, may indicate an early phase of rising sea level that is clearly marked by the transgressive surface at the base of unit $\mathrm{C}$ (fig. 17). Relative sea level continued to rise during deposition of the lower half of unit $\mathrm{C}$, as indicated by upward-deepening facies, and may have reached a plateau during deposition of the upper half of unit $\mathrm{C}$ (fig. 17).

The erosive contact at the base of unit $\mathrm{D}$ represents abrupt shallowing to nonmarine conditions, and the transgressive surface at the base of unit $\mathrm{E}$ indicates renewed deepening, which continued throughout the deposition of this unit (fig. 17). Although these inferences are straightforward, it is unclear whether unit D represents an abrupt drop in base level or simply a fluvial flood event.

Units F, G, I, and J are inferred to represent progressive deepening (fig. 17); however, each of these units is relatively uniform lithologically, and the contacts between units are gradational over short intervals. Therefore, the inferred relativesea-level curve includes plateaus (relatively constant or gradually rising sea level) and steps (pulses of rising sea level; fig. 17). Unit $H$, which is the only sandstone in this succession, is interpreted as a pulse of slope-channel turbidite deposition. An abrupt drop in relative sea level is inferred during deposition of unit $\mathrm{H}$ as a possible trigger of turbidite deposition (fig. 17), although this depositional event could also have been triggered by outer-shelf and upper-slope instability caused by depositional oversteepening or an earthquake in the absence of any change in relative sea level.

Unit $\mathrm{K}$ is unique in the Siksikpuk River section in that it comprises a series of conglomerate and sandstone beds that suggest significant incision of the slope and, possibly, mass wasting of the shelf margin and upper slope, indications of an abrupt drop in relative sea level (fig. 17).

Unit L, which is nearly uniform lithologically throughout, is inferred to be a marine-slope deposit. Relative sea level is interpreted to have remained nearly constant during deposition of this unit except during pulses of slope-channel turbidite deposition (units $\mathrm{M}$ through Q). As with unit $\mathrm{H}$, an abrupt drop in relative sea level is inferred during deposition of these units as a possible trigger of turbidite deposition (fig. 17).

The interpretations presented above assume that slope incision and accumulation of slope-channel deposits (units $\mathrm{H}$, $\mathrm{K}$, and $\mathrm{M}$ through $\mathrm{Q}$ ) resulted from drops in relative sea level. Alternatively, any or all of these events may have been triggered by outer-shelf and upper-slope instability in the absence of any drop in relative sea level. Mechanisms that could have triggered such instability include depositional oversteepening of the shelf margin, earthquakes related to tectonic faulting, and methane exhalation. 


\section{Key Surfaces and Systems Tracts}

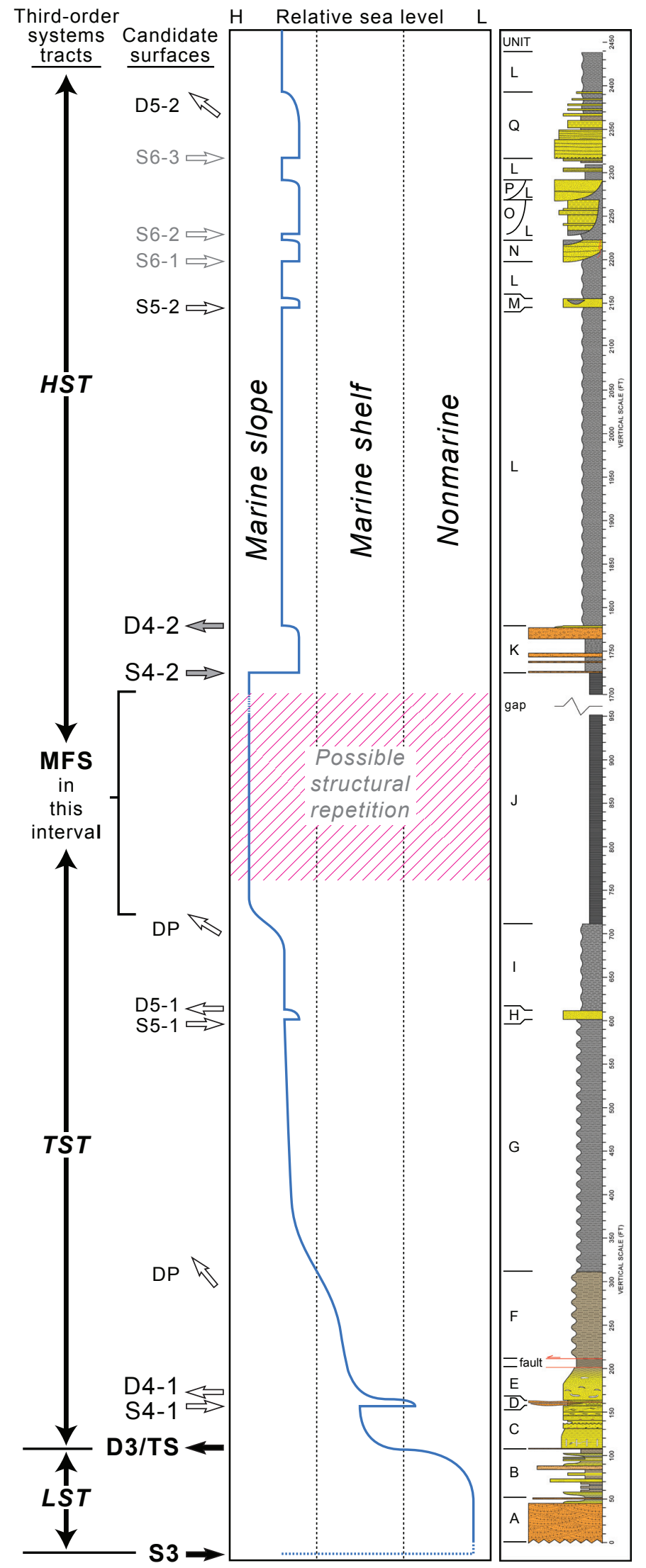

Interpretations of depositional facies and relative sea level suggest that depositional sequences spanning four orders of scale are represented in the Siksikpuk River section (see pl. 1; fig. 1). Placement of these sequences into the hierarchies proposed by other workers (for example, Vail and others, 1991) is difficult because of poor age resolution and limited knowledge of lateral dimensions. Depositional sequences representing longer periods of geologic time and larger stratigraphic dimensions are well known in Arctic Alaska (Hubbard and others, 1987; Bird and Molenaar, 1992; Houseknecht, 2006), and so these depositional sequences are here referred to as third through sixth order for the sake of discussion.

The entire Siksikpuk River section (see pl. 1; fig. 1) is inferred to represent part of a single third-order depositional sequence that includes parts of several higher-order depositional sequences (fig. 17). Although the sub-Fortress Mountain contact is not exposed, the contact between Torok slope facies and the nonmarine facies of unit $\mathrm{A}$ is interpreted as a thirdorder-sequence boundary (surface S3, fig. 17) just beneath the measured section. The sharp base of unit $\mathrm{C}$ is interpreted as a third-order drowning/transgressive surface (D3/TS), and units $\mathrm{A}$ and $\mathrm{B}$ together are interpreted as a lowstand-systems tract (LST) of the third-order depositional sequence.

Units $\mathrm{C}$ through $\mathrm{J}$ constitute generally deepening upward marine facies interpreted as a transgressive-systems tract (TST) of the third-order depositional sequence. The relatively abrupt gradations between units $\mathrm{F}$ and $\mathrm{G}$ and between units I and $\mathrm{J}$ suggest that the rise in relative sea level did not occur at a constant rate (relative to sediment flux), and so these gradations are interpreted as deepening pulses (surface DP, fig. 17). A maximum-flooding surface (MFS) is inferred to be present in the structurally complex unit J (fig. 17). The rest of the Siksikpuk River section (see pl. 1; fig. 1), comprising marine-slope and slope-channel facies, is interpreted as a highstand-systems tract (HST) of the third-order depositional sequence (fig. 17).

Figure 17. Inferred relative-sea-level curve, candidate sequence-stratigraphic surfaces, and systems tracts of thirdorder depositional sequence for Siksikpuk River measured section (pl. 1; fig. 1). D3/TS, drowning surface of third-order depositional sequence and transgressive surface; D4-n, drowning surface of fourth-order depositional sequence $n$; D5-n, drowning surface of fifth-order depositional sequence n; DP, deepening pulse; HST, highstand-systems tract; LST, lowstand systems tract; MFS, maximum-flooding surface; S3, sequence boundary of third-order depositional sequence; $S 4-n$, sequence boundary of fourth-order depositional sequence $n$; $S 5-n$, sequence boundary of fifth-order depositional sequence $n$; $S 6-n$, sequence boundary of sixth-order depositional sequence $n$; TST, transgressive-systems tract. Units A through $L$ on measured section at right are same as those identified on plate 1 . 
Key surfaces that may represent parts of higher-order sequences nested within the third-order depositional sequence are also present. The bases and tops of units D and $\mathrm{K}$, inferred to mark abrupt drops and rises in relative sea level, respectively, are interpreted as fourth-order-sequence boundaries (surfaces S2-1 and S2-2, respectively, fig. 17) and drowning surfaces (D4-1, D4-2). Thus, units D and $\mathrm{K}$ are interpreted as the LSTs of fourth-order depositional sequences, signifying the potential for more widespread deposits of sandstone-prone facies farther basinward.

The base and top of unit $\mathrm{H}$ are interpreted as a sequence boundary (surface S5-1, fig. 17) and drowning surface (D5-1), respectively, and unit $\mathrm{H}$ as the LST of a fifth-order depositional sequence.

The series of slope-channel deposits near the top of the measured section (fig. 1) can be interpreted similarly. Although each slope-channel deposit (units M through Q) may represent a fifth-order depositional sequence, more probably units $\mathrm{M}$ through $\mathrm{Q}$ represent a composite fifth-order depositional sequence. Thus, the base of unit $\mathrm{M}$ and the top of unit $\mathrm{Q}$ are interpreted as the sequence boundary (surface S5-2, fig. 17) and drowning surface (D5-2), respectively, of a fifth-order depositional sequence, and each slope-channel deposit within that interval is interpreted as part of a sixth-order depositional sequence (or, possibly, simply a parasequence). The erosive bases of the sixth-order depositional sequences are labeled surfaces S6-1 through S6-3 (fig. 17).

\section{Accommodation and Sediment Flux}

The results presented above can be used to consider accommodation and sediment flux during deposition of the Siksikpuk River section (see pl. 1; fig. 1). At the base of the measured section, the shift from marine-slope to proximalnonmarine deposition (surface S3, fig. 17) suggests a reduction in accommodation space, possibly reflecting either a drop in eustatic sea level or tectonic uplift at the site of deposition. Although the biostratigraphic resolution in the Siksikpuk River section and nearby outcrops (fig. 1, table 1) precludes accurately correlating the stratigraphic section to global eustaticsea-level curves, a significant drop in global sea level-either at the Barremian-Aptian boundary (Haq and others, 1988) or in the mid-Aptian (Sahagian and Jones, 1993) — is a candidate for a contributing event.

Sediment supply must be considered in the regional context of a huge sediment flux (Crowder, 1987; Molenaar and others, 1988) and significant variation in the thickness of the Fortress Mountain Formation, which is apparent in aerial photographs (fig. $1 B$ ) and has been documented by other workers (Crowder, 1987; Molenaar and others, 1988; Wartes and Carroll, 2002). In fact, the Fortress Mountain Formation in the Siksikpuk River section (see pl. 1; fig. 1) appears to be among the thinnest parts of the formation (fig. $1 B$ ). If the observed drowning/transgressive surface (D3/TS, fig. 17) can be used as an approximately horizontal reference surface near the top of the Fortress Mountain
Formation and if that surface is assumed to approximate sea level, then the thickness of the underlying LST provides a minimum estimate of the accommodation space that was filled to base level during deposition. In this context, the modest thickness of the LST of the third-order depositional sequence (fig. 17) at the Siksikpuk River section probably resulted from limited accommodation space-in other words, the LST thins toward the Siksikpuk River section as a result of onlap onto a relatively high part of an irregular depositional surface. Considering the thicker successions of Fortress Mountain Formation deposited nearby, presumably along depositional strike (fig. 1), the modest thickness of the LST at the Siksikpuk River section cannot be attributed to bypass of sediment to more basinward sites of deposition. These conclusions suggest that the area of the Siksikpuk River section was tectonically uplifted, probably at the onset of Fortress Mountain deposition. The effects of this uplift may have been exacerbated if the uplift overlapped in time with a drop in global sea level.

The TST of the third-order depositional sequence at the Siksikpuk River section (see pl. 1; fig. 1) is unusually thick and characterized by relatively abrupt facies changes, inferred to represent pulses of deepening. During deposition of this TST, the rate at which accommodation space was added slightly exceeded the rate of sediment influx, and so the succession is retrogradational. The addition of accommodation space is attributable to the early Aptian rise in global sea level (Haq and others, 1988; Sahagian and Jones, 1993) or to accelerated basin subsidence, possibly induced by tectonic loading. The distinctive pulsed deepening may further reflect tectonic loading at the basin margin.

The HST of the third-order depositional sequence at the Siksikpuk River section (see pl. 1; fig. 1) ranges from mostly aggradational (lower $\sim 300 \mathrm{ft}$ of unit L, fig. 17) to progradational (units $\mathrm{M}$ through $\mathrm{Q}$ ). Basin subsidence driven by tectonic or sedimentary loading may account for the additional accommodation space, although the near balance between accommodation and sediment influx may favor sedimentary loading. Sediment influx during deposition of this HST likely was related to early phases of the regional sediment-dispersal system responsible for progradation of the Torok-Nanushuk couplet in Aptian and Albian time (Bird and Molenaar, 1992; Houseknecht and Schenk, 2001).

\section{Inferred Seismic Expression}

A paucity of seismic data and the degree of structural deformation near the Siksikpuk River section (see pl. 1; fig. 1) preclude direct correlation of the measured section to the subsurface. Nevertheless, certain inferences are possible regarding the likely seismic expression of these strata. The Torok Formation underlying the Fortress Mountain Formation is interpreted as a marine-slope facies in nearby outcrops. Farther north in the basin, Torok marine-slope facies are well documented to display clinoform seismic expression (Molenaar, 1985, 1988; 
McMillen, 1991; Bird and Molenaar, 1992; Houseknecht and Schenk, 2001, 2005). Therefore, we assume that the Torok marine-slope facies underlying the Fortress Mountain Formation in the study area (fig. 1) similarly would display clinoform seismic expression, although synsedimentary tectonic activity may have deformed those clinoforms.

The Fortress Mountain Formation and the lower part of the overlying Torok Formation (units A through G, fig. 17) are inferred to have been deposited in nonmarine through shallowmarine environments on a depositional surface that sloped gently basinward. The seismic expression of this interval of the measured section (fig. 1) certainly would be topset reflections (see pl. 1). The boundary between underlying clinoforms of the Torok marine-slope facies and these topset reflections is inferred to display toplap.

The rest of the Torok Formation in the measured section (unit $\mathrm{H}$ to top of section, pl. 1; fig. 1) is inferred to have been deposited in a marine-slope environment punctuated by multiple, high-order lowstand events. These facies and their sequence-stratigraphic framework are similar to those observed in the Torok Formation farther north in the basin, where they display seismic clinoforms (Molenaar, 1985, 1988; McMillen, 1991; Bird and Molenaar, 1992; Houseknecht and Schenk, 2001, 2005), and so a similar seismic expression is inferred for these strata. The contact between these clinoforms and the underlying topset seismic reflections is inferred to be an erosional sequence boundary (base of unit $\mathrm{H}, \mathrm{pl} .1$ ). Therefore, the base of the clinoforms would be defined by a surface that truncates the underlying topset reflections, and the clinoforms may onlap that erosional surface.

Partial analogs for the overall seismic expression of the measured section (fig. 1) were illustrated by Houseknecht and Schenk (2005, fig. 3). In the west half of that image, the seismic expressions of the Torok, Nanushuk, and Seabee Formations are generally similar to the inferred seismic expression of the Siksikpuk River section (see pl. 1; fig. 1), although the Seabee clinoforms are unusually thin and do not rest on a distinct erosional surface. Near the east end of the same seismic image, a similar overall seismic expression is displayed by clinoforms in the Seabee Formation overlain by topsets of the Tuluvak and lower part of the Schrader Bluff Formations, in turn overlain by clinoforms in the Canning Formation. Thus, the erosional contact between seismic topsets of the Tuluvak and lower part of the Schrader Bluff Formations and overlying clinoforms of the Canning Formation are probably more nearly analogous to the relation between the Fortress Mountain and Torok topsets and the overlying Torok clinoforms in the Siksikpuk River section.

If these seismic analogs and sequence-stratigraphic interpretations are appropriate, they place the Siksikpuk River section (see pl. 1; fig. 1) relatively close to a shelf margin at the time when nonmarine and shallow-marine parts of the Fortress Mountain and Torok Formations (topset seismic facies) were deposited. This interpretation suggests that the Siksikpuk River section was deposited along the southern depositional margin of the Colville foreland basin.

\section{Conclusions}

A nearly continuous exposure of $>2,400 \mathrm{ft}$ of the Lower Cretaceous Fortress Mountain and Torok Formations along the Siksikpuk River in north-central Alaska (see pl. 1; fig. 1) provides a rare opportunity to observe a stratigraphic contact between these formations and to interpret the depositional facies and sequence stratigraphy of these strata. The upper $200 \mathrm{ft}$ of the Fortress Mountain Formation includes braided-fluvial, coastalplain, and transgressive-shoreface deposits; the overlying Torok Formation includes $>2,000 \mathrm{ft}$ of marine-shelf and marine-slope facies, as well as incised slope-channel turbidite deposits. A gamma-ray profile collected through the Siksikpuk River section (pl. 1) correlates well with described lithofacies and may provide an analog for interpretation of wireline logs from approximately coeval strata in the subsurface elsewhere in the basin.

Analysis of the vertical succession of depositional facies suggests that the lower $\sim 100 \mathrm{ft}$ of measured section (fig. 1) was deposited during a lowstand of relative sea level, that the middle $\sim 1,600 \mathrm{ft}$ of measured section (including possible structural repetition) was deposited during a general rise in relative sea level, and that the upper $\sim 700 \mathrm{ft}$ of measured section was deposited during a highstand of relative sea level. These inferred trends in relative sea level define a third-order depositional sequence comprising (1) an LST at the base of the section, (2) a TST in the middle of the section, and (3) an HST at the top of the section. The inferred TST is further characterized by distinct pulses of deepening within a gradually deepening upward succession. Multiple higher-order depositional sequences are nested within the third-order depositional sequence, as evidenced by key stratigraphic surfaces and vertical successions of facies that indicate abrupt fluctuations in relative sea level throughout the measured section.

In the context of regional sediment flux during deposition of lower Brookian strata and of local variation in the thickness of the Fortress Mountain Formation, the onset of LST deposition may suggest localized tectonic uplift, possibly overlapping in time with an early or middle Aptian drop in relative sea level. TST deposition may reflect a rise in global sea level or, possibly, subsidence induced by tectonic loading. The pulses of deepening inferred in the TST suggest pulses of basin subsidence that may have been caused by tectonic loading at the basin margin. The succession of facies in the HST suggests an upward gradation from mostly aggradational to progradational sedimentation. The near balance between accommodation and sediment influx may reflect basin subsidence driven primarily by sediment loading.

The seismic expression of the Fortress Mountain and Torok Formations in the study area (fig. 1) is inferred to include clinoforms of the Torok Formation (beneath the measured section) toplapping into topset reflections of the Fortress Mountain (units A through E, pl. 1) and the shallow-marine part of the overlying Torok Formation (units F and G, pl. 1). These topsets are likely truncated by a basinward-dipping erosional sequence boundary, which is onlapped by clinoforms of the Torok Formation (unit $\mathrm{H}$ to top of section, pl. 1). Seismic 
analogs from farther north in the basin, in combination with sequence stratigraphic constraints, suggest that the Siksikpuk River section was deposited along the southern depositional margin of the Colville foreland basin.

\section{References Cited}

Bird, K.J., and Molenaar, C.M., 1992, The North Slope foreland basin, Alaska, in Macqueen, R.W., and Leckie, D.A., eds., Foreland basins and fold belts: American Association of Petroleum Geologists Memoir 55, p. 363-393.

Carman, G.J., and Hardwick, P., 1983, Geology and regional setting of Kuparuk oil field, Alaska: American Association of Petroleum Geologists Bulletin, v. 67, no. 6, p. 10141031.

Cole, F., Bird, K.J., Toro, J., Roure, F., O’Sullivan, P.B., Pawlewicz, M., and Howell, D.G., 1997, An integrated model for the tectonic development of the frontal Brooks Range and Colville basin $250 \mathrm{~km}$ west of the trans-Alaska crustal transect: Journal of Geophysical Research, v. 102, no. B9, p. 20685-20708.

Crowder, R.K., 1987, Cretaceous basin to shelf transition in northern Alaska; deposition of the Fortress Mountain Formation, in Tailleur, I., and Weimer, P., eds., Alaskan North Slope geology: Bakersfield, Calif., Society of Economic Paleontologists and Mineralogists, Pacific Section, and Alaska Geological Society, v. 1, p. 449-458.

Crowder, R.K., 1989, Deposition of the Fortress Mountain Formation, in Mull, C.G., and Adams, K.E., eds., Dalton Highway, Yukon River to Prudhoe Bay, Alaska: Alaska Division of Geological and Geophysical Surveys Guidebook 7, p. 293-301.

Gradstein, F.M., and Ogg, James, 1996, A Phanerozoic time scale: Episodes, v. 19, no. 1-2, p. 3-5.

Grasty, R.L., Carson, J.M., Charbonneau, B.W., and Holman, P.B., 1984, Natural background radiation in Canada: Geological Survey of Canada Bulletin 360, 39 p.

Haq, B.U., Hardenbol, J., and Vail, P.R., 1988, Mesozoic and Cenozoic chronostratigraphy and cycles of sea-level change, in Wilgus, C.K., Hastings, Ross, C.A., B.S., Posamentier, H., Van Wagoner, J., and Kendall, C.G.S.C., eds., Sea-level changes; an integrated approach: Society of Economic Paleontologists and Mineralogists Special Publication 42, $\mathrm{p}$. 71-108.

Houseknecht, D.W., 2006, Early Cretaceous to Tertiary evolution of the Colville foreland basin-linked tectonics and sedimentation [abs.]: Geological Society of America Abstracts with Programs, v. 38, no. 5, p. 88-89.
Houseknecht, D.W., and Schenk, C.J., 2001, Depositional sequences and facies in the Torok Formation, National Petroleum Reserve-Alaska (NPRA), in Houseknecht, D.W., ed., 2001, NPRA Core Workshop-Petroleum Plays and Systems in the National Petroleum Reserve-Alaska: Society of Economic Paleontologists and Mineralogists Core Workshop 21, p. 179-199.

Houseknecht, D.W., and Schenk, C.J., 2005, Sedimentology and sequence stratigraphy of the Cretaceous Nanushuk, Seabee, and Tuluvak Formations exposed on Umiat Mountain, north-central Alaska: U.S. Geological Survey Professional Paper 1709-B, 18 p. [URL http://pubs.usgs.gov/pp/ pp 1709b/].

Houseknecht, D.W., and Schenk, C.J., in press, Outcrops of turbidite channel facies in the Torok Formation; reservoir analogs for the Alaska North Slope, in Nilsen, T., Shew, R.D., Steffens, G.S., and Studlick, J.R.J., eds., An atlas of deepwater outcrops-models and analogs: American Association of Petroleum Geologists Special Publication.

Hubbard, R.J., Edrich, S.P., and Rattey, R.P., 1987, Geologic evolution and hydrocarbon habitat of the "Arctic Alaska microplate": Marine and Petroleum Geology, v. 4, no. 1, p. 2-34.

Huffman, A.C., Jr., ed., 1985, Geology of the Nanushuk Group and related rocks, North Slope, Alaska: U.S. Geological Survey Bulletin 1614, 129 p.

Hunter, R.E., and Fox, J.E., 1976, Interpretation of depositional environments in the Fortress Mountain Formation, central Arctic Slope, in Cobb, E.H., ed., The United States Geological Survey in Alaska-accomplishments during 1975: U.S. Geological Survey Circular 733, p. 30-31.

Lerand, M., 1973, Beaufort Sea, in McCrossan, R.G., ed., The future petroleum provinces of Canada-their geology and potential: Canadian Society of Petroleum Geology Memoir 1, p. 315-386.

Lowe, D.R., 1982, Sediment gravity flows; II. Depositional models with special reference to the deposits of high-density turbidity currents: Journal of Sedimentary Petrology, v. 52, no. 1, p. 279-297.

McMillen, K.J., 1991, Seismic stratigraphy of Lower Cretaceous foreland basin submarine fans in the North Slope, Alaska, in Weimer, P., and Link, M.H., eds., Seismic facies and sedimentary processes of submarine fans and turbidite systems: New York, Springer-Verlag, p. 289-302.

Mickey, M.B., 2006, Foraminifera report on 2000 and 2005 outcrop field samples and USGS/Husky North Kalikpik No. 1 cores, North Slope, Alaska: Encinitas, Calif., report to U.S. Geological Survey under contract 06ERSA0470, 42 p. 
Molenaar, C.M., 1983, Depositional relations of Cretaceous and lower Tertiary rocks, northeastern Alaska: American Association of Petroleum Geologists Bulletin, v. 67, no. 7, p. 1066-1080.

Molenaar, C.M., 1985, Subsurface correlations and depositional history of the Nanushuk Group and related strata, North Slope, Alaska, in Huffman, A.C., Jr., ed., Geology of the Nanushuk Group and related rocks, North Slope, Alaska: U.S. Geological Survey Bulletin 1614, p. 37-59.

Molenaar, C.M., 1988, Depositional history and seismic stratigraphy of Lower Cretaceous rocks in the National Petroleum Reserve in Alaska and adjacent areas, in Gryc, G., ed., Geology and exploration of the National Petroleum Reserve in Alaska, 1974 to 1982: U.S. Geological Survey Professional Paper 1399, p. 593-621.

Molenaar, C.M., Egbert, R.M., and Krystinik, L.F., 1988, Depositional facies, petrography, and reservoir potential of the Fortress Mountain Formation (Lower Cretaceous), central North Slope, Alaska, in Gryc, G., ed., Geology and exploration of the National Petroleum Reserve in Alaska, 1974 to 1982: U.S. Geological Survey Professional Paper 1399, p. 257-280.

Moore, T.E., Wallace, W.K., Bird, K.J., Karl, S.M., Mull, C.G., and Dillon, J.T., 1994, Geology of northern Alaska, in Plafker, G., and Berg, H.C., eds., The geology of Alaska, v. G-1 of The geology of North America: Boulder, Colo., Geological Society of America, p. 49-140.

Mull, C.G., 1985, Cretaceous tectonics, depositional cycles, and the Nanushuk Group, Brooks Range and the Arctic Slope, Alaska, in Huffman, A.C., Jr., ed., Geology of the Nanushuk Group and related rocks, North Slope, Alaska: U.S. Geological Survey Bulletin 1614, p. 7-36.

Mull, C.G., Houseknecht, D.W., and Bird, K.J., 2003, Revised Cretaceous and Tertiary stratigraphic nomenclature in the Colville basin, northern Alaska: U.S. Geological Survey Professional Paper 1673, 51 p. [URL http://pubs.usgs.gov/ pp/p1673/].
Peapples, P.R., Wallace, W.K., Wartes, M.A., Swenson, R.F., Mull, C.G., Dumoulin, J.A., Harris, E.E., Finzel, E.S., Reifenstuhl, R.R., and Loveland, A.M., 2007, Geologic map of the Siksikpuk River area, Chandler Lake quadrangle, Alaska: Alaska Geological and Geophysical Surveys Preliminary Interpretive Report 2007-1, scale 1:63,360 [URL http://wwwdggs.dnr.state.ak.us/pubs/pubs?reqtype=citation $\& I D=15757]$.

Ravn, R.L., 2006, Palynology report; U.S. Geological Survey outcrop samples, North Slope, Alaska: Anchorage, report to U.S. Geological Survey under contract 06ERSA0472, 1 p.

Sahagian, D., and Jones, M., 1993, Quantified Middle Jurassic to Paleocene eustatic variations based on Russian Platform stratigraphy — stage level resolution: Geological Society of America Bulletin, v. 105, no. 8, p. 1109-1118.

Tourtelot, H.A., and Tailleur, I.L., 1965, Oil yield and chemical composition of shale from northern Alaska: U.S. Geological Survey Open-File Report 66-131, 17 p.

U.S. Geological Survey Geologic Names Committee, 2007, Divisions of geologic time-major chronostratigraphic and geochronologic units: U.S. Geological Survey Fact Sheet 2007-3015, 2 p. [URL http://pubs.usgs.gov/fs/2007/3015/].

Vail, P.R., Audemard, F., Bowman, S.A., Eisner, P.N., and Perez-Cruz, C., 1991, The stratigraphic signatures of tectonics, eustasy and sedimentology_an overview, in Einsele, G., Ricken, W., and Seilacher, A., eds., Cycles and events in stratigraphy: Berlin, Springer-Verlag, p. 617-659.

Walker, R.G., and Plint, A.G., 1992, Wave- and storm-dominated shallow marine systems, in Walker, R.G., and James, N.P., eds., Facies models-response to sea level change: St. Johns, Newfoundland, Geological Association of Canada, p. 219-238.

Wartes, M.A., and Carroll, A.R., 2002, Detailed facies analysis of the Lower Cretaceous Fortress Mountain Formation, Atigun syncline, northern Alaska [abs.]: American Association of Petroleum Geologists Bulletin, v. 86, no. 6, p. 1162. 